\title{
INFLUENCIA DEL ICONO ORIENTAL EN EL ARTE SACRO CONTEMPORÁNEO: LA OBRA DE RUPNIK Y ARGÜELLO EN LA CATEDRAL DE LA ALMUDENA DE MADRID
}

\author{
Influence of the Eastern Icon on Contemporary Sacred Art: The Work \\ of Rupnik and Argüello in the Cathedral of La Almudena in Madrid
}

\author{
María Diéguez Melo \\ dieguezmelo@gmail.com \\ Universidad de Salamanca. España \\ Fecha de recepción: 01/04/2020 \\ Fecha de aceptación: 07/06/2020
}

Resumen: El mundo del arte sacro contemporáneo vive en las últimas décadas un retorno a la figuración vinculado al redescubrimiento de los iconos. Diferentes autores han vuelto la vista a la tradición oriental para retomar un camino de la imagen sagrada que en la Iglesia de Occidente ya se había perdido en aras de una cierta iconoclastia especialmente presente en las décadas centrales del siglo XX.

Superando estos momentos de crisis de la imagen sagrada, vinculados especialmente al Movimiento Litúrgico y su expresión arquitectónica a través del funcionalismo alemán, se observa una decidida actitud de recuperación del icono como categoría especialmente propicia para la creación de arte sacro y litúrgico, redescubriéndose también, en un ámbito más teórico, la teología asociada a estas expresiones plásticas. Por ello, descubrimos a lo largo de las últimas décadas una recuperación del icono que se extiende más allá de los límites del mundo ortodoxo, creando caminos de influencias recíprocas entre Oriente y Occidente.

En el presente texto se analizará la influencia del icono oriental en el arte sacro contemporáneo a través del estudio de las aportaciones que Kiko Argüello y Marko Ivan Rupnik han hecho en la catedral de La Almudena de Madrid entre 2004 y 2011. El estudio comparado de distintas iconografías permitirá apreciar la asunción y reinterpretación de modelos orientales como vehículo de renovación del arte sacro occidental.

Palabras clave: icono; arte sacro; Kiko Argüello; Marko Ivan Rupnik; Catedral de La Almudena. 


\begin{abstract}
The world of contemporary sacred art has experienced in recent decades a return to figuration linked to the rediscovery of icons. Different authors have turned to the Eastern tradition to retake a path of the sacred image that in the Church of the West had already been lost for the sake of a certain iconoclasm especially present in the central decades of the 20th century.

Overcoming these moments of crisis of the sacred image, especially linked to the Liturgical Movement and its architectural expression through German functionalism, a determined attitude of recovery of the icon is observed as a category especially conducive to the creation of sacred and liturgical art, also rediscovering itself, in a more theoretical sphere, the theology associated with these plastic expressions. For this reason, we have discovered over the last decades a recovery of the icon that extends beyond the limits of the Orthodox world, creating paths of reciprocal influences between East and West.

In this paper, the influence of the oriental icon in contemporary sacred art will be analyzed through the study of the contributions that Kiko Argüello and Marko Ivan Rupnik have made in the Cathedral of La Almudena in Madrid between 2004 and 2011. The comparative study of different Iconographies will allow us to appreciate the assumption and reinterpretation of eastern models as a vehicle for the renewal of western sacred art.
\end{abstract}

Keywords: Icon; sacred art; Kiko Argüello; Marko Ivan Rupnik; Catedral de La Almudena.

SUMARIO: 1. Introducción. 2. Influencia del icono oriental en el arte sacro contemporáneo: la obra de Rupnik y Argüello. 3. Programas iconográficos de Rupnik y Argüello en la catedral de la Almudena: una lectura occidental de la tradición oriental. 3.1. Bautismo. 3.2. Transfiguración. 3.3. Crucifixión. 3.4. Anástasis, Tumba vacía y Resurrección. 3.5. Pentecostés. 3.6. Ascensión. 3.7. Pantocrátor. 4. Conclusión. 5. Referencias bibliográficas

\title{
1. INTRODUCCIÓN
}

Una mirada al panorama del arte sacro actual nos confirma que la práctica iconográfica se extiende más allá de los límites de la Iglesia oriental, siempre guardiana de la tradición ortodoxa del icono. A pesar de que el arte occidental cuenta con obras de arte sacro del más alto nivel y que el icono no es la una única tipología artística que puede formar parte de la categoría del arte litúrgico, sí es cierto que, por sus características, sería una de las más altas expresiones pictóricas de la teología cristiana. El mensaje del icono y su trascendencia eclesial sigue vigente en época contemporánea por lo que, en un tiempo tan visual como el nuestro, la ilustración del dogma por medio de imágenes sacras vuelve a ser un medio para la evangelización, como bien señalan Špidlík y Rupnik (2013b).

Esta revalorización del arte iconográfico ya había aparecido en la Iglesia oriental que, desde el siglo XIX, inicia un camino de recuperación de modelos plásticos al que acompaña un creciente interés teológico. En este sentido, Rusia se convierte en un caso paradigmático a la hora de analizar la comunicación bidireccional entre Oriente y Occidente ya que, a lo largo de su arte iconográfico, observamos un camino de ida y vuelta de modelos e influencias. Referente para el icono codificado en escuelas como Nóvgorod o Moscú, Rusia es también la cuna de grandes iconógrafos 
como Andrei Rublev, cuyas obras han asentado modelos de gran trascendencia. Sirva de caso del icono de la Trinidad (c. 1422-28) conservado en la Galería Tretiakov de Moscú, obra creada para el iconostasio de la catedral de la laura de la Trinidad y San Sergio de Zagorsk. La relevancia que adquieren en toda la Iglesia oriental obras como esta, unido a la difusión de modelos bizantinos tan célebres como la Virgen de Vladimir, icono del s. XII trasladado a Kiev desde Constantinopla, convierten el caso ruso en un caso particular a la hora de analizar la llegada de influencias occidentales, el abandono de la ortodoxia en los siglos XVIII y XIX y su reciente recuperación.

Desde sus orígenes griegos y bizantinos, el icono ruso adquiere en el medievo un estilo formalista de gran intensidad expresiva en las figuras, usando tonalidades características como los rojos y naranjas de las escuelas de Kiev y Nóvgorod ${ }^{1}$. En el siglo XIV, el centro artístico se traslada a Moscú, codificando la clásica distribución del iconostasio con su representación de las doce fiestas, la deesis y las imágenes de Cristo y la Virgen María. De este momento es la obra de Teófanes el Griego ${ }^{2}$ y Andrei Rublev $^{3}$, fuente este último de muchos de los modelos utilizados en Occidente.

Ya en la Edad Moderna, las líneas de separación entre Oriente y Occidente empiezan a mostrarse permeables, haciéndose visible una clara influencia italiana en la pintura de iconos que irá abandonando las referencias bizantinas para acoger prácticas propias del Renacimiento (Uspenski, 2013, pp. 327-375). Esta introducción de lo occidental no se circunscribe exclusivamente a las cuestiones plásticas, sino que se producirá una entrada en Rusia de la reforma protestante y una implantación de la teología escolástica que sin duda ayudaron al abandono de la doctrina ortodoxa sobre la concepción de la imagen, frente a lo cual advierte el gran concilio de Moscú celebrado entre 1666 y 1667.

En la práctica artística, los iconógrafos de este momento cultivan una renovación del arte pictórico que incorpora a los iconos influencias occidentales visibles en el claroscuro y la búsqueda de tridimensionalidad. Las obras resultantes serán más realistas y narrativas, como puede apreciarse en la producción del iconógrafo

${ }^{1}$ Destacan los frescos de la iglesia del Salvador (Nereditsa) y la iglesia de San Jorge (Stáraya Ládoga) además de obras sobre tabla. Esta escuela, que incorpora elementos locales al arte iconográfico, presenta figuras menos hieráticas en composiciones claras y fácilmente legibles de gran dinamismo. Además, a lo largo de los siglos se crearon escuelas regionales de gran importancia como Vladímir o Pskov.

2 En la producción de este autor destacan los frescos de la iglesia de la Transfiguración (1378, Nóvgorod), el icono Nuestra Señora del Don (1380), los frescos de la iglesia de la Natividad de María del Kremlin (1395, Moscú), los frescos de la Catedral del arcángel en el Kremlin de Moscú (1399) y de la Catedral de la Anunciación, del Kremlin. Además, junto a Andréi Rublev y Prójor de Gorodéts (1405) es autor del icono de la Transfiguración (1408) conservado en la Galería Tretiakov.

${ }^{3}$ Entre la obra de Andrei Rublev hay que reseñar los frescos de la Catedral de la Anunciación, del Kremlin, realizados junto a Teófanes el Griego y Prójor de Gorodéts (1405), y los frescos de la Catedral de la Asunción en Vladimir, además del celebérrimo icono de la Trinidad (c. 1422). 
Dionisio ${ }^{4}$ o de Simon Ushakov ${ }^{5}$ (1626-1686), los cuales demuestran la decadencia de la ortodoxia iconográfica a partir del siglo XVII y la importancia creciente de la orfebrería decorativa, que poco a poco invade una mayor superficie.

Esta influencia occidental se entiende en el mundo ortodoxo como una crisis del arte sacro, que en su caso se ejemplificó en época barroca con la alteración del canon tradicional y la introducción de nuevos modelos más realistas y tridimensionales. Por ello, Alfredo Sáenz considera que los problemas que el arte sacro ha experimentado a lo largo del siglo xx en la Iglesia de Occidente también se pueden percibir en el mundo ortodoxo. Así, achaca la decadencia producida en el arte iconográfico oriental al influjo que produjeron los artistas occidentales a finales del siglo XVII introduciendo ideas renacentistas y esteticistas que provocaron cambios en el arte ruso de los iconos (1991, pp. 438-443). Esta influencia se concretó en la apertura a otras temáticas y técnicas no comunes en la iconografía ortodoxa, como es el caso de los temas profanos y naturales y la pintura al óleo. Como ejemplo elocuente del rechazo y olvido de la tradición, cita el hecho de que Catalina la Grande mandara retirar de la catedral de la Asunción de Vladimir el iconostasio realizado por Rublev para colocar en su lugar uno de estilo barroco. Siguiendo la pauta regia, estos iconostasios barrocos y neoclásicos se extendieron por toda Rusia, dejando a un lado la imagen tradicional y propiciando la pérdida de algunas de estas obras que, en el mejor de los casos, quedaron relegadas a almacenes para dar paso a una modernidad que buscaba la creación de un arte nacional ruso.

Hubo que esperar hasta los inicios del siglo xx para comenzar a reencontrar estas obras olvidadas por cambios de gusto o por caer en el desuso $0^{6}$, observándose que muchas de ellas presentaban daños producidos por las condiciones de su almacenaje. Estos iconos fueron repulidos o restaurados, descubriéndose y difundiéndose la grandeza del arte iconográfico a través de estudios y exposiciones. Destaca especialmente la muestra de arte antiguo en Rusia realizada en Moscú en 1913, debido a que entre los fondos de esta se encontraban obras maestras de los

${ }^{4}$ Del maestro Dionisio, llamado el Sabio (ca.1440 - 1502), destacan la serie de iconos para la Catedral de la Dormición en el Kremlin de Moscú (1481) y los frescos de la Catedral de la Natividad de la Virgen en el Monasterio de Ferapóntov (1495-96).

${ }^{5}$ La producción de Simon Ushakov es muy variada llegando a ser uno de los protegidos de la familia real. Entre su producción, con una coloración más viva y clara, destaca el retrato de Teodoro I de Rusia (h. 1650), Nuestra Señora de Eleus (1668), Cristo-Emanuel (1668), Arcángel Miguel pisoteando al demonio con sus pies (1676) y la Última Cena (1685).

${ }^{6}$ No hay que olvidar que la vida de un icono no solía superar el siglo ya que por la utilización de aceites y el humo de las velas e inciensos hacía que se oscureciera la capa pictórica. En muchos casos, sobre el diseño original, se repasaba la imagen de una forma más o menos fiel al original, consiguiendo así alargar la vida de este. Las nuevas técnicas de restauración ayudaron a que en el siglo xx se pudiera recuperar la viveza de los colores conservados bajo lacas, aceites y pigmentos. 
siglos XIV al XVI pertenecientes a las escuelas de Moscú y Nóvgorod que habían sido restauradas para la ocasión.

El redescubrimiento de la viveza de las composiciones abrió la puerta para la recuperación del arte del icono en el siglo $\mathrm{xx}$, no solo en el ámbito artístico sino también a través de los grandes estudios sobre estética teológica y teología del icono que acompañaron, de forma teórica, a las nuevas obras plásticas. Después de 1918 , las colecciones de iconos, mismas que se entienden como parte de una herencia cultural, pasan a ser propiedad estatal, asumiendo el Estado soviético su restauración, organización y promoción, aunque esto no suponga, en ningún caso, una postura más cercana a la religión.

Tras estos momentos iniciales, donde la conservación y restauración son tareas primordiales, la corriente de recuperación de la tradición iconográfica en Rusia se vinculó a la rehabilitación de la Iglesia ortodoxa, lo cual une la cuestión artística con el ámbito histórico-político. Este restablecimiento institucional hará posible la recuperación de escuelas históricas y la promoción de nuevos talleres, además del reconocimiento de las grandes obras del medievo que habían sido incluidas en las colecciones museográficas de la Galería Tretiakov de Moscú y el Museo Pushkin de San Petersburgo.

Aunque en el seno de la Iglesia ortodoxa, se puede observar una recuperación del propio icono que puede parecer desvinculada del pensamiento teológico y de la piedad litúrgica, en realidad, como bien señala Uspensky, "el renacimiento contemporáneo del icono no es ni un anacronismo ni una adhesión al pasado o al folclore, ni siquiera un intento de hacer que renazca la imagen sagrada en el taller de un pintor. Se trata de una toma de conciencia de la Iglesia, de la ortodoxia, de un regreso por medio del arte a la transmisión auténtica de la experiencia patrística, del verdadero conocimiento de la revelación cristiana» (Uspensky, 2013, p. 527). En opinión de este autor, el redescubrimiento de los iconos es uno de los hechos más relevantes desde el punto de vista artístico y espiritual, señalando además que las nuevas obras no se entienden como una recuperación historicista sino que se retoma como parte de un presente para el cual «el icono ya no representa un simple valor artístico o cultural, sino que supone, a través del arte, una revelación de la experiencia espiritual ortodoxa, una "teología en imágenes» que ya se había manifestado en el pasado» (Uspensky, 2013, pp. 477-478).

Este reconocimiento trasciende lo meramente artístico u ornamental haciendo más sencilla su adopción en un ámbito occidental católico, el cual buscaba nuevos referentes que permitieran la rehabilitación de la via pulchritudinis. La Iglesia de Occidente se muestra inmersa en una búsqueda de expresiones plásticas a lo largo del siglo $\mathrm{xX}$, apareciendo algunas tendencias que pueden entenderse como iconoclastas. De hecho, las expresiones arquitectónicas vinculadas al Movimiento Litúrgico, especialmente el funcionalismo litúrgico alemán 
de Dominkus Böhm, Rudolf Schwarz y Emil Steffann (Marín, 2012), mostrarán un escaso uso de las artes plásticas en el espacio celebrativo. La influencia de los presupuestos arquitectónicos de Adolf Loos y Peter Behrens cristalizados en la Bauhaus suponen en la construcción de templos que estos se destaquen por una sencillez y racionalidad en las cuales no parecía tener cabida un aporte plástico. Asumiendo estos principios encontramos iglesias como el Corpus Christi de Aquisgrán (R. Schwarz, 1928), el Espíritu Santo en Frankfurt (M. Weber, 1931), San Engelbert en Colonia (D. Böhm, 1931-1933), San Lorenzo de Munich (E. Steffann, 1955) o Santa Ana en Düren (R. Schwarz, 1951-1956) en las cuales, como señala Plazaola, «lo notable, lo nuevo y lo desconcertante para muchos en aquel momento era la simplicidad, la pureza y la desnudez abrumadoras del volumen central: ni columnas, ni partición del espacio, ni decoración ni ornamentación alguna» (Plazaola, 1965, p. 306).

Superando estos momentos de crisis de la imagen sagrada, se observa una recuperación plástica expresada en vertientes abstractas o figurativas. En estas últimas, destaca una decidida recuperación iconográfica que trasciende los límites entre Oriente y Occidente. En el presente texto analizaremos la influencia del icono oriental en el arte sacro contemporáneo mediante la lectura en paralelo de las aportaciones que Kiko Argüello y Marko Ivan Rupnik han hecho en la catedral de Santa María la Real de la Almudena de Madrid entre 2004 y 2011. Los programas decorativos del ábside, la capilla del Santísimo, la sacristía y la sala capitular de la seo madrileña permiten acercarnos a la visión personal de estos artistas que, sin renegar de la modernidad plástica, asumen y reinterpretan modelos orientales en su intento de renovación del arte sacro occidental.

\section{INFLUENCIA DEL ICONO ORIENTAL EN EL ARTE SACRO CONTEMPORÁNEO: LA OBRA DE RUPNIK Y ARGÜELLO}

Al atender la recuperación del icono en el arte sacro contemporáneo descubrimos la labor, entre otros muchos autores, del esloveno Marko Ivan Rupnik, el español Kiko Argüello, el mexicano fray Gabriel Chávez de la Mora OSB. y el brasileño Claudio Pastro. Aunque todos ellos han creado una plástica personal influenciada por el icono oriental, sin duda la obra de los dos primeros, por su amplia difusión internacional, reviste una singular importancia.

Marko Ivan Rupnik es un sacerdote jesuita nacido en Zadlog (Eslovenia) en 1954. En 1973 ingresa en la Compañía de Jesús y, durante su etapa de formación, inicia su trayectoria artística, expresando en ella sus inquietudes espirituales. Con estudios de filosofía, también se forma en la Academia de Bellas Artes de Roma, estudiando teología en la Pontificia Universidad Gregoriana de Roma. Su obra refleja la unión de su formación filosófica, teológica y artística lo cual también se 
manifiesta en sus trabajos académicos. Desde sus primeras investigaciones trata de acercarse a una lectura del significado teológico del arte moderno y, con este planteamiento, aborda la elaboración de su tesis de licenciatura sobre Kandinsky, en la que intenta ver esta obra a la luz de la teología rusa, y su tesis doctoral en misionología, titulada El significado teológico misionero del arte en la ensayística de Vjačeslav Ivanovič Ivanov. Siguiendo esta unión entre práctica artística y mundo académico, en la actualidad es docente del Pontificio Instituto Oriental de Roma y en la Pontificia Universidad Gregoriana, siendo además el director desde 1995 del Taller de arte espiritual del Centro Aletti y consultor del Pontificio Consejo para la Cultura desde 1999. Como artista ha realizado diversas exposiciones personales desde 1979 hasta la actualidad en muy diversos países como EE. UU. (1979, 1980), Italia (1979, 1987, 1988, 1997), Eslovenia (1980, 1981, 1985, 1992), Croacia (1982), Austria (1991), Rusia (1996) o República Checa (1997).

En sus primeras obras muestra un gran conocimiento de las vanguardias, tomando para su producción especialmente lo relativo a la utilización del color y la forma como medio de expresión. En la producción de la década de los ochenta se pude ver la clara influencia de Van Gogh, Kandinsky y el fauvismo, especialmente en la autonomía cromática, la libertad formal y el uso del color como base para la configuración de una obra personal de trazos gruesos y expresivos. Poco a poco, como respuesta plástica a sus inquietudes espirituales, ha ido viviendo un cambio en su arte que le ha llevado a la concreción de un estilo figurativo inspirado en la tradición oriental del icono para el que ha recuperado la técnica del mosaico. Así ha llegado a una práctica artística de taller, colectiva y cooperativa, en la cual se dan cita el estudio, la creación artística y la vivencia eclesial.

En el caso de Francisco José Gómez de Argüello Wirtz, conocido como Kiko Argüello, nace en León en 1939, formándose en la Academia de Bellas Artes de San Fernando. En los años 50 inicia su labor pictórica realizando obras de temática no religiosa que se adentran en la vanguardia. Fruto de este momento es la obra La espera (1958), la cual obtiene el premio extraordinario en el Primer Certamen Juvenil de Arte celebrado en 1959. Coincidiendo con el final de su periodo formativo, sufre una crisis existencial que lo orientará a lo religioso, abriendo un camino definitivo para su pintura. Sus contactos con el P. José Manuel de Aguilar y el Movimiento Arte Sacro le permiten realizar un viaje por Europa destinado a la búsqueda de elementos coincidentes entre el arte protestante y el arte católico de cara al Concilio Vaticano II. De vuelta de este viaje, funda el grupo de investigación y desarrollo del Arte Sacro «Gremio 62» junto al escultor Coomonte y el vidrierista Muñoz de Pablos con la intención de renovar el arte religioso a través de un cambio plástico y espacial orientado a responder a la aparente desarticulación que observaban en las iglesias del momento. Con este grupo realizará exposiciones en la Dirección General de Bellas Artes (1963), la sala de exposiciones «Templo y altar» de Madrid (1964) y la Galería Nouvelles Images de La 
Haya (Holanda), participando también en la exposición de arte sacro celebrada en Rouen (Francia) en 1965.

A mediados de los años sesenta, tras una experiencia en el poblado chabolista de Palomeras Altas, inicia el Camino Neocatecumenal junto a Carmen Hernández. Este hecho supondrá un evento definitivo para su creación, vinculada casi de forma exclusiva a este itinerario reconocido por las entidades eclesiales como «una modalidad de realización diocesana de la iniciación cristiana y de la educación permanente de la fe, según las indicaciones del Concilio Vaticano II y del Magisterio de la Iglesia» (SCN, art. 1\&1).

En el plano artístico, la búsqueda de renovación del arte religioso que Argüello había iniciado con el grupo Gremio 62 continúa hasta la definición de la Nueva Estética Neocatecumenal misma que consiste en un proyecto global para el espacio celebrativo que abarca todas las artes desde la pintura, el proyecto arquitectónico, las vidrieras y los signos y ornamentos litúrgicos. Esta propuesta estética, codificada por primera vez en la parroquia florentina de San Bartolomeo in Tuto (1978-1998), presenta un aporte pictórico de clara filiación oriental basado en la reinterpretación de las doce fiestas del iconostasio que se trasladan a retablos en el ábside o a la denominada "corona mistérica» [Fig. 1], una suerte de friso corrido situado bajo la cúpula.

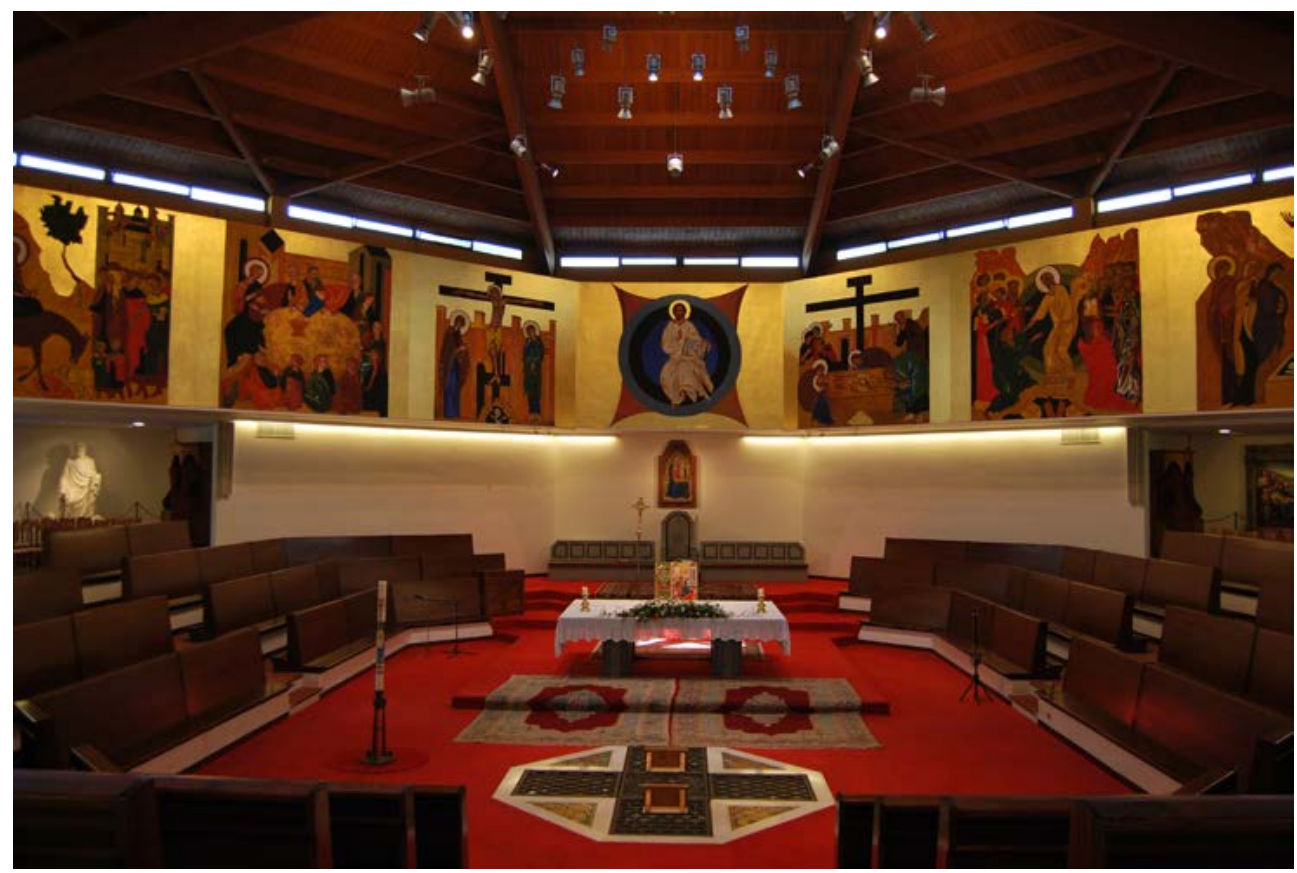

Fig. 1. Kiko Argüello. Corona mistérica, 1984-98. San Bartolomeo in Tuto (Scandicci, Florencia). 
Estas breves pinceladas biográficas nos muestran dos artistas preocupados por la renovación del arte sacro actual que, en varios sentidos, presentan una trayectoria paralela que los ha llevado a la adopción de modelos orientales en su creación contemporánea. Previo al estudio de su aportación en la catedral de la Almudena, esbozaremos un breve análisis comparativo que permita trazar paralelismos entre ambos, señalando sus puntos comunes y diferencias para ver cómo se ha abordado esta recuperación del icono. Para realizar este estudio atenderemos distintas cuestiones fundamentales: formación, inicio de su trayectoria artística, estilo e influencias y metodología de trabajo. En definitiva, se busca reflejar la trayectoria paralela que ambos autores han realizado hasta desembocar en la adopción de modelos iconográficos orientales como como fuente principal de inspiración para su labor de creación de un arte litúrgico contemporáneo.

En cuanto a su formación, hay que destacar que en ambos se unen los aspectos artísticos y teológicos. Sin embargo, es Rupnik el que ha realizado un estudio más profundo en distintas ramas de conocimiento ya que, como parte de su noviciado en los jesuitas, se ha formado en teología y filosofía, además de estudiar en la Academia de Bellas Artes de Roma. Fruto de esta formación, son distintos estudios artísticoteológicos donde ha relacionado la teología y el arte contemporáneo. Por ejemplo, en su tesis de licenciatura se centra en la obra de Kandinsky en un estudio titulado Vassili Kandinsky como acercamiento a una lectura del significado teológico del arte moderno a la luz de la teología rusa. Por otra parte, su tesis doctoral ahonda en el valor del arte como vehículo evangelizador y se titula El significado teológico misionero del arte en al ensayística de Viaceslav Ivanoniv Ivanov. Estos textos demuestran sus grandes conocimientos teóricos sobre teología y pensamiento oriental, a la vez que son un ejemplo de interés por la plástica contemporánea. A lo largo de los últimos años, ha realizado también una serie de publicaciones entorno a su obra arte que, junto con entrevistas, lecciones teológicas, conferencias artísticas y artículos especializados, nos permiten conocer en profundidad su pensamiento artístico.

Por su parte, la formación de Argüello se orientó esencialmente al ámbito de las artes. Ya hemos apuntado que se forma como pintor en Real Academia de Bellas Artes de San Fernando en Madrid, aunque, a lo largo de su vida, ha profundizado en el conocimiento de teología, historia de la iglesia, el cristianismo primitivo y la renovación litúrgica derivada del Concilio Vaticano II. De hecho, su labor como iniciador del Camino Neocatecumenal, le ha hecho merecedor de doctorados honoris causa en Sagrada Teología ${ }^{7}$. En relación con sus escritos y publicaciones, una obra fundamental a la hora de conocer su periplo vital es El Kerigma. En las chabolas con los pobres (2012), mientras

7 En los últimos años, como reconocimiento a su persona y a la labor del Camino Neocatecumenal, se le han concedido dos doctorados honoris causa. El primero de ellos, en Sagrada Escritura, fue concedido el 13 de mayo de 2009 por el Instituto Pontificio Juan Pablo II para estudios sobre el matrimonio y la familia (Roma) y el segundo, en Sagrada Teología se le otorgó por la Universidad Católica de Lublín (Polonia) el 26 de junio de 2013. 
que su pensamiento artístico se ha manifestado, fundamentalmente, en la explicación de sus obras realizada, en la mayoría de los casos, el día de la bendición de las pinturas o de la consagración de la iglesia, momento en el cual acostumbra a explicar la iconografía representada, con alusiones a la técnica, materiales y las fuentes artísticas.

Al establecer el inicio de su actividad artística, se observa que ambos autores tuvieron un despertar artístico temprano y ya, desde su juventud, manifiestan su interés por el arte, iniciando su formación en la academia y realizando sus primeras obras. En el caso de Argüello, sus primeras creaciones son de finales de los años cincuenta: una obra de tipo secular, como se puede ver en el lienzo La espera (1959) que presenta una escena costumbrista. Poco a poco su trayectoria camina hacia los contenidos religiosos, plasmando también en este giro su propia búsqueda espiritual, que lo encamina a la fundación del grupo para la renovación del arte sacro Gremio 62 junto a Coomonte y Muñoz de Pablos (Diéguez, 2018).

En el caso de Rupnik, su obra comienza en torno a 1973 durante sus inicios en el noviciado de los jesuitas, momento en el cual pide permiso a sus superiores para adquirir útiles de pintura que le sirven para plasmar sus vivencias espirituales en esas obras de juventud.

Al comparar los inicios de ambos autores podemos observar que el periodo formativo les sirve para adentrarse en la plástica contemporánea, conociendo la vanguardia y las nuevas corrientes artísticas, de las cuales toman elementos de inspiración que hasta día de hoy pueden rastrearse en sus obras y que nos trasladan a hablar de las influencias presentes en su obra.

Con relación a las influencias que han recibido, en el caso de Rupnik destaca la interpretación de la autonomía del color de Van Gogh, la libertad formal de Kandinsky y la expresión colorista del fauvismo y Matisse. En el ámbito teórico, sus referencias se centran en la obra De lo espiritual en el arte de Kandinsky y la teología relacional de Ivanov, principalmente. En el caso de Argüello, su obra presenta influencias diversas en cada una de sus etapas creativas, mirando en distintos momentos hacia la vanguardia, de la que cita especialmente a Matisse, Braque y Picasso, y el arte paleocristiano hasta llegar al arte oriental, encontrando en Rublev su principal fuente para la recuperación del icono.

Otro de los aspectos que vincula la obra de ambos artistas es una suerte de "conversión estilística». Este término, utilizado por María Rodríguez Velasco en su estudio sobre Rupnik (Rodríguez Velasco, 2014, p. 11), creemos que puede aplicarse a ambos artistas ya que los dos han experimentado un "camino hacia las fuentes» del arte cristiano en el cual han ido centrando su mirada en la tradición de la Iglesia, especialmente en las imágenes-signo de la época paleocristiana y en la tradición oriental. En el caso de Rupnik, este viaje va desde la abstracción al icono, uniendo la tradición artística paleocristiana y bizantina con un lenguaje moderno para la creación de arte litúrgico. Por parte de Argüello, no se puede considerar que parta de la abstracción ya que desde sus inicios su obra es eminentemente figurati- 
va pero sí es significativo que su larga búsqueda de renovación del arte sacro haya concluido también en la vuelta al icono como valor expresivo del espacio litúrgico.

Además, a pesar de sus diferencias estilísticas y técnicas, es necesario señalar que, en la actualidad, ambos entienden la obra de arte litúrgico como un arte total que debe atender a otros elementos del espacio litúrgico, además de la imagen. Así, en el caso de la labor del Centro Aletti, se ha iniciado el trabajo de vidrieras y realización de altares, sagrarios o tabernáculos, torres eucarísticas ${ }^{8}$. En los últimos años, especialmente desde 2006, y teniendo el precedente de la Capilla Redemptoris Mater del Vaticano, Rupnik y sus colaboradores han comenzado a trabajar de forma conjunta todos los focos de la liturgia ${ }^{9}$. Un ejemplo de este trabajo global es la cripta de la iglesia inferior de San Pío de Pietrelcina en San Giovanni Rotondo [Fig. 2], donde Rupnik realiza el diseño de los focos litúrgicos y la decoración pictórica que abarca todas las paredes ${ }^{10}$.

${ }^{8}$ En el caso de la Capilla Redemptoris Mater del Vaticano (1996-1999) también se realizaron la sede, el ambón, la cruz y la pila de agua. Sin embargo, la creación de estos focos litúrgicos es mucho menos habitual que la realización del altar o la custodia eucarística.

9 Sirvan de ejemplo otras obras como el sagrario, el altar y el ambón de la capilla de las Hermanas Adoratrices del Santísimo Sacramento de Lenno (Italia 2007); la iglesia de San Juan Bautista en Cassino (Italia, 2011) en la que se hicieron el ambón y el altar; la torre eucarística, el altar y el ambón de la capilla del Santísimo de la Catedral de Santa María la Real de la Almudena en Madrid (2011); la torre eucarística de la iglesia del beato Claudio en Chiampo (Italia, 2012); la decoración y los focos litúrgicos de la capilla de la Estación de Santa Maria Novella en Florencia (Italia, 2012); la iglesia del Corpus Domini en Bolonia (Italia, 2013) en la que se ha realizado altar, ambón, torre eucarística y cruz.

Otro ejemplo de este trabajo dirigido a todos los focos litúrgicos se puede ver en la iglesia de Santa María de la Consolación de Altamura (Italia, 2013), en la cual ha realizado la torre eucarística, el altar, el ambón, la fuente bautismal y la base para el cirio pascual. Este caso es de gran interés ya que las vidrieras en la puerta de acceso a la nave central con la representación de la anunciación son también habituales en la obra de Argüello (Domus Galilaeae-Israel; Parroquia de Santa Catalina Labouré-Madrid; Parroquia de Nuestra Señora del Pilar-Valdemoro), vinculándose este particular a las puertas reales del iconostasio bizantino que son reflejo plástico de la vinculación teológica entre el inicio de la redención y la entrada en la iglesia.

10 Esta distribución de las escenas en un hemiciclo puede recordar a la distribución que Argüello hace de sus obras en lo que él denomina "corona mistérica» que en el caso de San Stefano Rotondo pasaría a estar al mismo nivel de los fieles. Si se quisiera buscar un ejemplo más cercano en cuanto a la distribución del aparato iconográfico tendríamos que referirnos a de Juan Pablo II de Cracovia, cuya decoración es realizada por Rupnik y el Centro Aletti en junio de 2013. En este espacio, que forma parte del «Centro Juan Pablo II» de la capital polaca, se pueden observar una serie de seis paneles rectangulares que circundan el espacio octogonal del templo justo bajo la cúpula, las cuales completan la decoración del ábside. En estos espacios se desarrolla una completa iconografía en la cual aparece la teofanía de Mambré, la epifanía y la anástasis (ábside) y el pecado original, la curación de los endemoniados, la tempestad callada, las bodas de Caná, el perdón a la adúltera y la curación del ciego de nacimiento y la última cena (corona). Esta disposición es similar a la realizada por Argüello en multitud de sus obras, siendo la primera de ellas la iglesia de San Bartolomeo in tuto en Scandicci (Italia). 


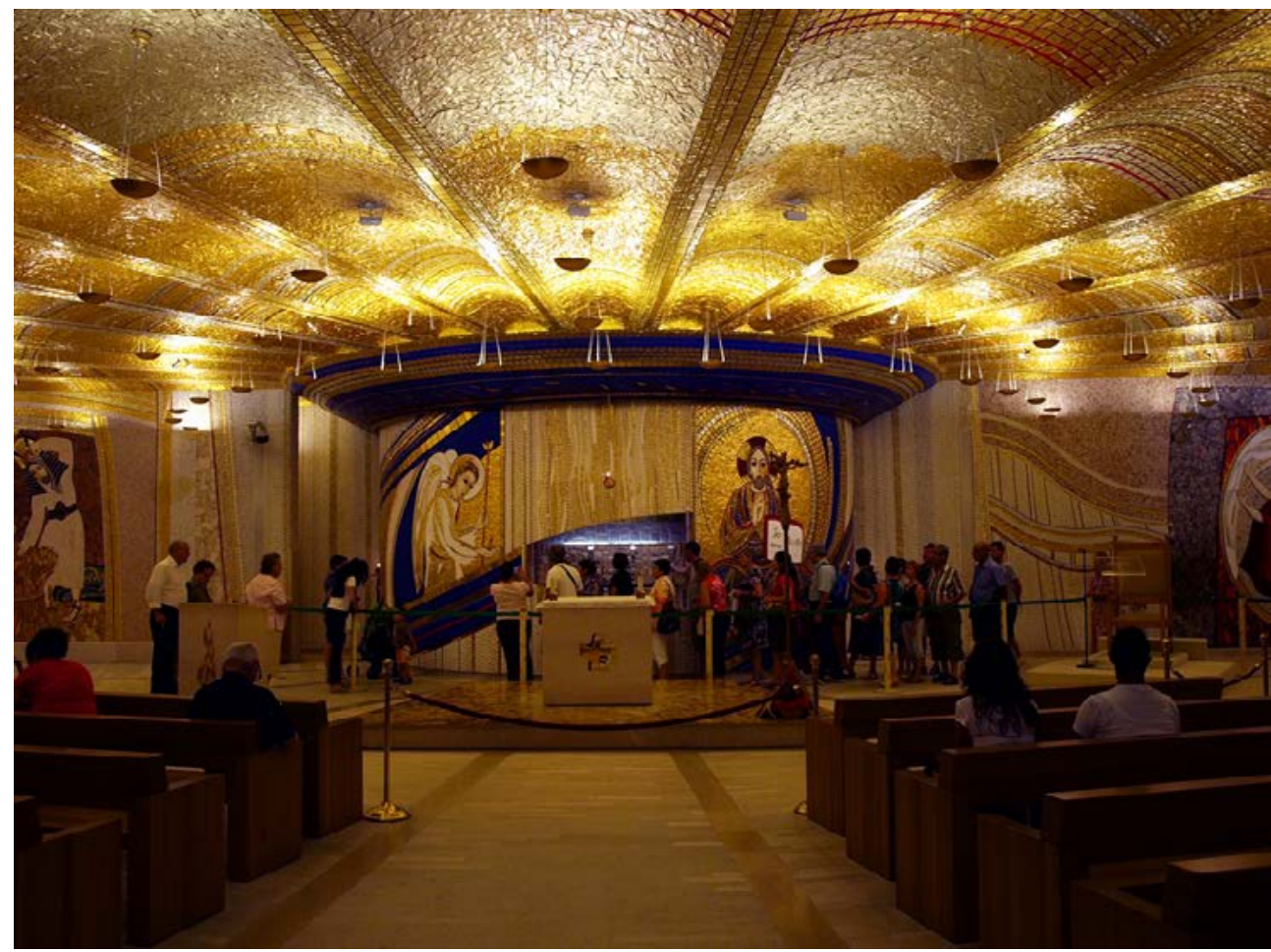

Fig. 2. Rupnik. Cripta de la iglesia inferior de San Pio de Pietrelcina, 2009. San Giovanni Rotondo (Italia).

En el caso de Argüello, hay que indicar que su preocupación por el espacio litúrgico abarca desde el suelo a los techos, atendiendo a todos los elementos presentes ya sean focos celebrativos, ajuar litúrgico, solado, vidrieras, paredes o cubiertas. Su colaboración con arquitectos hace que las obras pictóricas realizadas por él, en colaboración con un grupo internacional de pintores, cuenten con un marco espacial que en su diseño combina un esquema de centralidad para la distribución de la asamblea y de axialidad para los focos litúrgicos.

Otro de los aspectos que relaciona la obra de ambos autores es su atención al tratamiento de la luz y la relación de esta con el espacio celebrativo. Además de atender a su incidencia a través de los vanos, es necesario referirse a la realización de vitrales que no solo animan el muro y tamizan la luz, sino que persiguen una profundidad iconográfica. Argüello ha realizado en este campo diseños de estilos muy diversos, llevando a cabo obras abstractas, figurativas y epigráficas [Fig. 3]. Un ejemplo que reúne estas tendencias es la propia Catedral de la Almudena donde coinciden la vidriera que representa el resucitado de la capilla central de la girola y las vidrieras epigráficas con fondo geométrico que están situadas sobre los iconos del ábside ${ }^{11}$.

11 Estos vitrales combinan el estilo figurativo y geométrico presente en el Centro Internacional de Porto San Giorgio (Italia) donde aparecen las primeras vidrieras con entramado 


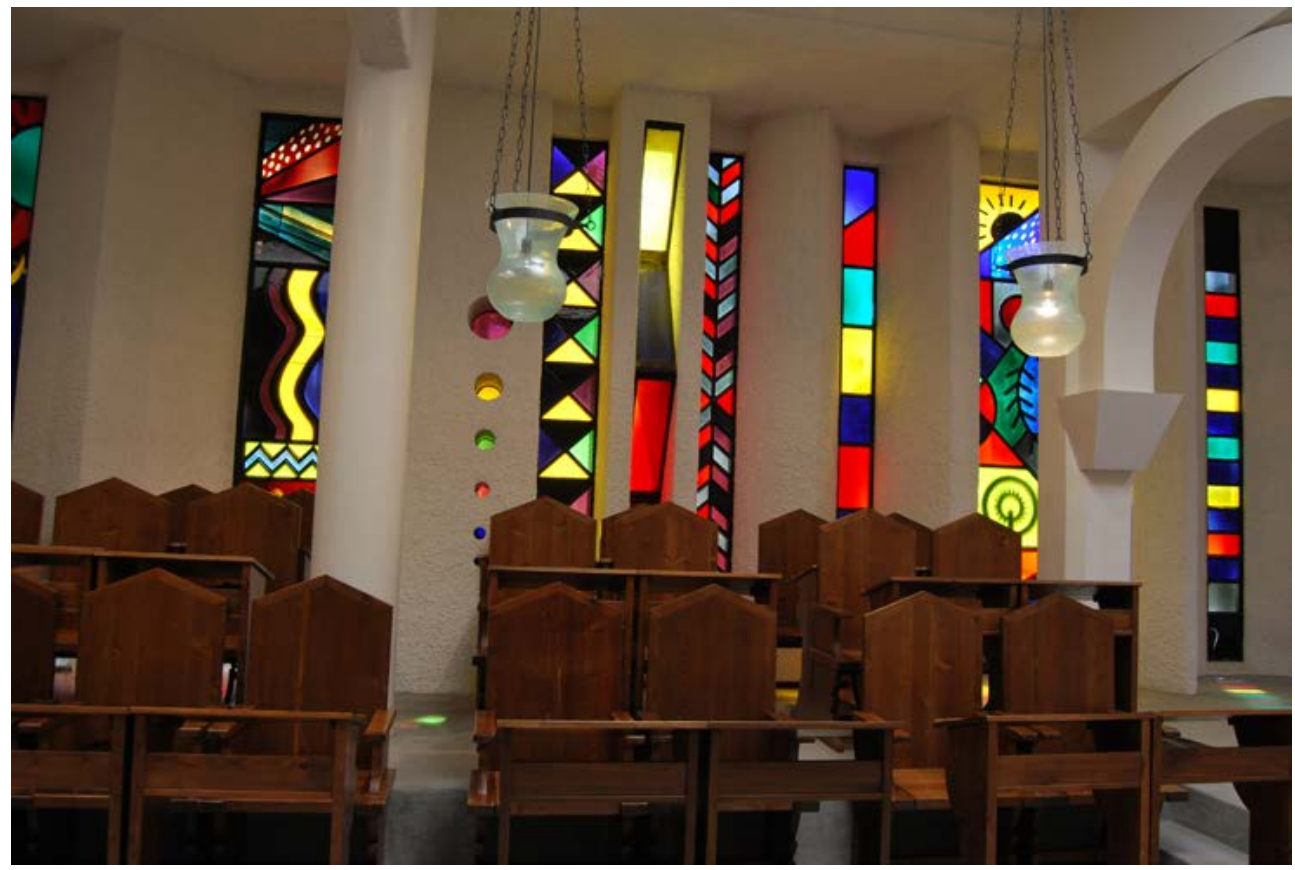

Fig. 3. Kiko Argüello. Vidrieras del Santuario de la Palabra. Seminario Redemptoris Mater, Roma (Italia)

Por su parte, las vidrieras realizadas por Rupnik, aunque siempre atentas al estudio lumínico, varían menos en cuanto a su estilo, siendo en la mayor parte de los casos de tipo epigráfico buscando una vinculación activa del fiel que se ve interpelado por la lectura del texto. En la elección de pasajes se aprecia una vinculación con el lugar que las acoge, expresando, por ejemplo, la espiritualidad ignaciana en los edificios jesuíticos o citas alusivas a la eucaristía en las capillas del Santísimo, pasando por un abundante uso de referencias bíblicas. En cuanto a la paleta cromática, la mayoría de los diseños optan por tonos cálidos, dorados y blanquecinos, como por ejemplo las vidrieras que realiza para las ventanas de la capilla de San José de las Hermanas de la Caridad de San Vicente de Paúl en Fiume (Rijeka, Croacia 2008) ${ }^{12}$.

de hormigón realizadas por Argüello mostrando una figuración vanguardista en la representación de la crucifixión, una figuración cercana a la iconografía en la Virgen del Silencio y una acusada abstracción en los paneles que representan la creación.

12 Aunque en un marco distinto y con tonalidades diferentes, son igualmente epigráficas las vidrieras de la capilla de la residencia de los jesuitas San Pedro Canisio en Roma (2007), las vidrieras tituladas "El Verbo se hizo carme» y "Yo lo veré, yo mismo» de la capilla Universitaria del Policlínico Humberto I de Roma (Italia, 2007) y las de la iglesia de Nuestra Señora del pozo (Líbano, 2008). Uno de los conjuntos más destacados, por la cantidad de vidrieras de tipo epigráfico realizadas es la capilla del Pontificio Colegio Irlandés de Roma (Italia, 2010) que cuenta con una serie de textos que casi hay que descifrar entre las formas geométricas en las que desarrollan. 
Finalmente, es necesario referirse al proceso de realización de las obras. A la hora de realizar sus obras, la labor de Rupnik y Argüello está vinculada a un grupo de arquitectos y artistas de diversa procedencia que colaboran en la concreción práctica de los proyectos. Este sistema de trabajo se basa en una fórmula fraternal de creación artística que se aparta de la individualidad contemporánea acercándolos a una forma de trabajo más propia del iconógrafo que está marcada por la ascesis, la oración y el ayuno.

En relación con el proceso de realización de los conjuntos iconográficos, es especialmente reseñable la vinculación de Rupnik con el Centro de Estudios e Investigaciones «Ezio Aletti», fundado en 1993 como parte del Pontificio Instituto Oriental. Su labor se orienta a la investigación y creación artística, promoviendo en todo momento el contacto ecuménico entre la Europa oriental y occidental a través del estudio y la práctica artística. Todo ello tiene como objetivo buscar una fisonomía espiritual cristiana de la cultura en la Europa de hoy sintetizando, cultural y teológicamente, la separación entre ayer y hoy, Oriente y Occidente, mediante el estudio teológico y de la cultura moderna y postmoderna.

Para la realización artística, este centro cuenta con un Atelier o Taller de arte espiritual que es un lugar de trabajo comunitario donde los artistas y colaboradores eventuales residen en el propio centro bajo un régimen de la vida comunitaria. Se podría decir que esta forma de trabajo conecta directamente con la época medieval ya que propone una unión entre taller artístico y scriptorium medieval, en el sentido de que el trabajo y la investigación se llevan a cabo en un ambiente de comunidad y oración donde el trabajo realizado es, en palabras del propio Rupnik, una obra coral. Se trataría de una metodología que intenta plasmar la teología trinitaria como interpretación eclesiológica la cual Rupnik vincula a una forma de trabajo colegiada:

He dicho que el mosaico es una obra coral. ¿Qué significa esta afirmación? Me he tomado muy en serio la teología trinitaria oriental para intentar ofrecer una interpretación eclesiológica. A la hora de crear, no tengo un proyecto preconcebido, ni siquiera lo he hecho para la capilla del Santo Padre, sino que se la he descrito. Mi método es el siguiente: dibujo directamente a escala real, sólo con carbón, sin colores, luego llego al espacio, distribuyo las figuras y después empiezo a crear porque falta todavía el $85 \%$ del mosaico y ¿cómo creo el conjunto? Lo primero es tener en cuenta a los artistas. Si yo tuviera un proyecto, ellos serían esclavos, meros ejecutores, pero el modo de gobernar la Iglesia es la colegialidad y eso supone que la verdad para a través de una comunión. (Rupnik, 2009a, p. 70).

Dentro de la vidriera epigráfica podríamos destacar las realizadas en la capilla de la Conferencia Episcopal Española (2011) que desarrollan un texto escrito en lengua latina entre figuras geométricas y fondo azulado. 
Además, el estudio de técnicas artísticas, teología, liturgia, Sagradas Escrituras y espiritualidad, permite que el resultado final no sea una obra arqueológica, sino que se recupera la tradición iconográfica antigua para trabajarla con los lenguajes de la Modernidad, aunque manteniendo la objetividad de la Liturgia que enlaza con el texto bíblico y patrístico. El resultado es una obra que enlaza con la época paleocristiana y el arte bizantino, pero conservando elementos del arte contemporáneo, algo especialmente visible en la Capilla Redemptoris Mater del Palacio Apostólico Vaticano, la cual quizás sea la obra más conocida de este Taller de Arte Espiritual.

Podemos concluir este análisis de la formación, trayectoria artística e influencias de Marko Ivan Rupnik y Kiko Argüello afirmando que la producción de ambos, sin menoscabar el estilo personal, muestra comunes referencias paleocristianas, bizantinas, románicas y góticas sin renunciar al lenguaje plástico propio de la vanguardia contemporánea, mostrando siempre una clara influencia del arte iconográfico oriental, utilizado siempre como base para la renovación de la plástica religiosa contemporánea.

\section{PROGRAMAS ICONOGRÁFICOS DE RUPNIK Y ARGÜELLO EN LA CATEDRAL DE LA ALMUDENA: UNA LECTURA OCCIDENTAL DE LA TRADICIÓN ORIENTAL}

Después de resaltar algunos de los fundamentos teóricos-prácticos comunes a la obra de Marko Ivan Rupnik y Kiko Argüello, sus obras en la catedral de Nuestra Señora la Real de la Almudena permite aterrizar el contenido en un caso concreto. Hemos elegido este ejemplo, entre las numerosas obras realizadas por estos autores $^{13}$, ya que en la seo madrileña no solo conviven en un mismo complejo catedralicio, sino que trabajan iconografías similares, lo cual nos permite poner frente a frente la obra de ambos autores. Siguiendo esta idea compararemos sus representaciones del bautismo, transfiguración, crucifixión, pantocrátor y la representación de la resurrección para ver sus similitudes y diferencias en cuanto a iconografía y estilo.

La labor de Rupnik y los artistas del Centro Aletti en la Catedral de la Almudena se ha desarrollado a lo largo de distintas campañas, en las cuales el trabajo se ha centrado en la decoración de distintos espacios del complejo catedralicio. Así, su

${ }^{13}$ Por circunscribir los ejemplos al ámbito madrileño, además de las intervenciones en la catedral, en esta diócesis Rupnik ha realizado la capilla del hospital Beata María Ana, la capilla de la Universidad San Pablo CEU y la capilla de la Conferencia Episcopal Española. Por su parte, y citado solo algunos ejemplos, Argüello ha llevado a cabo el diseño del complejo parroquial y los murales de Santa Catalina Labouré y numerosas obras pictóricas en las parroquias de La Paloma y el Tránsito o el Centro Neocatecumenal Diocesano de la calle Blasco de Garay. 
obra puede contemplarse en la sacristía (septiembre 2005), la sala capitular (octubre 2006) y la capilla del Santísimo (junio 2011). Estos espacios desarrollan programas iconográficos que, siguiendo sugerencias temáticas del cardenal Antonio María Rouco Varela y con el estilo habitual del Taller de Arte Espiritual del Centro Aletti, se centran en la expresión de una teología trinitaria para el espacio de la sala capitular, la creación y la redención en la sacristía y temas eucarísticos para la capilla del Santísimo.

Por su parte de la obra de Argüello en la catedral madrileña se realizó en el año 2004, momento en el que se le encarga la decoración de los paneles del ábside central y la realización de una serie de vidrieras para los vanos de este, conjunto que se completa con una última vidriera en la capilla central de la girola [Fig. 4]. Esta intervención desarrolla una serie de "pinturas murales [que] en su conjunto forman así una "Corona mistérica» dado que representan aquellos misterios que desde lo alto de cada paño del presbiterio poligonal anuncian lo que se celebra y se realiza en el altar: "Anunciamos tu muerte, proclamamos tu resurrección, ven Señor Jesús"» (Arguello, 2001, p.9). Estas escenas de la vida de Cristo y la escatología se completan con la serie de vidrieras epigráficas en las que se representa el vocablo "palabra» es distintas lenguas junto con el nombre de la Virgen en la vidriera que ocupa el eje central.

Las iconografías representadas en estos espacios son comunes a la historia del arte cristiano y por ello no es de extrañar que hayan sido utilizadas por ambos autores. Nos centraremos en nuestro análisis en aquellas que han sido representadas por ambos artistas en este complejo catedralicio, es decir el bautismo, la transfiguración, la crucifixión, la resurrección y tumba vacía y el pantocrátor, para finalizar el estudio con una breve alusión a otras escenas, como la ascensión y pentecostés, que Argüello realiza en el ábside central y que Rupnik ha llevado a cabo en la sacristía y la sala capitular. 


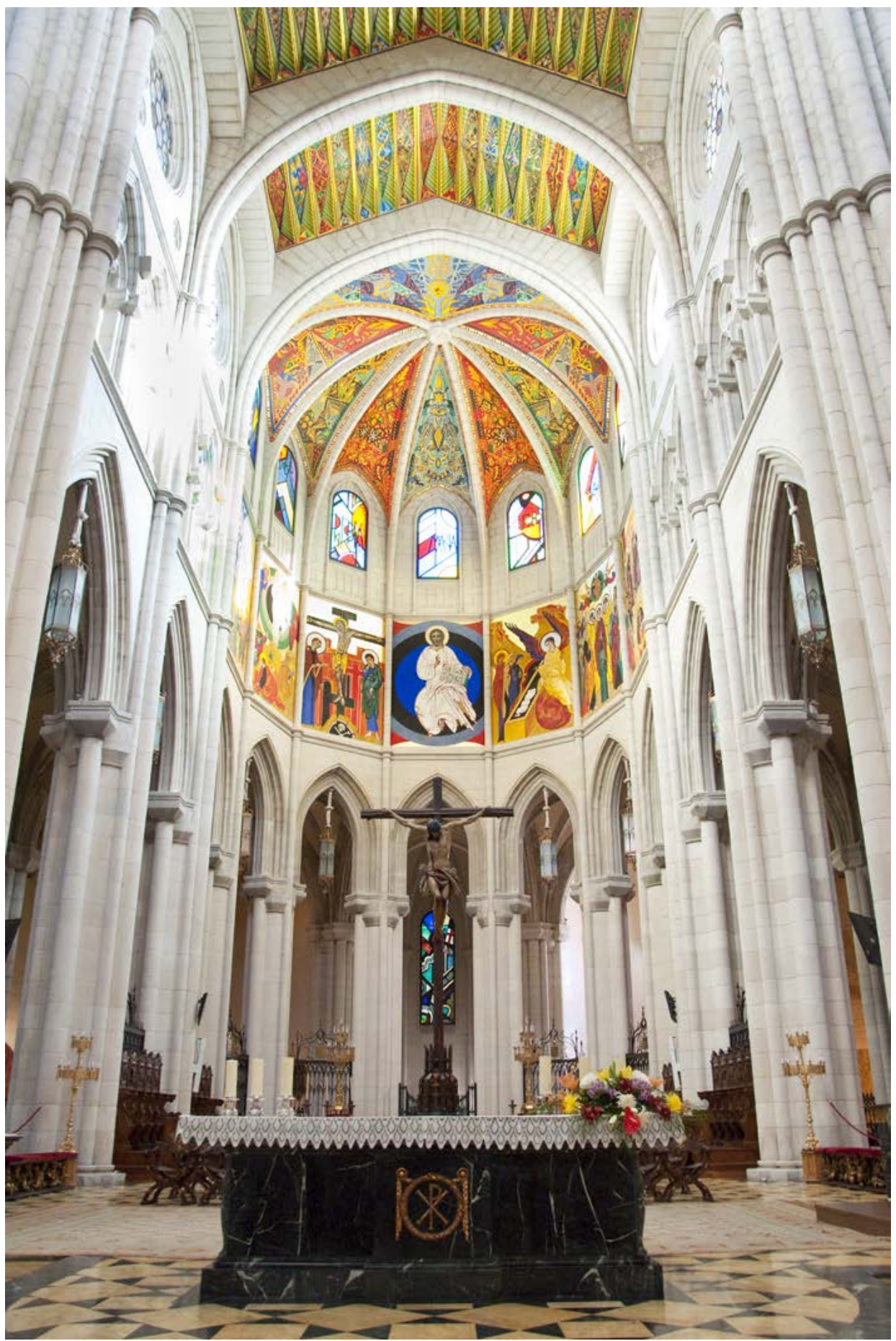

Fig. 4. Kiko Argüello. Pinturas del ábside, 2004. Catedral de la Almudena (Madrid). 


\subsection{Bautismo}

La primera de las iconografías analizadas es el bautismo, momento que, por su vinculación con el comienzo de la vida pública y su relación con el primero de los sacramentos de iniciación cristiana, es uno de los más repetidos en el arte cristiano, apareciendo en el complejo catedralicio de la Almudena en el ábside y la sacristía.

El mosaico del bautismo que es obra de Rupnik junto con el taller de Arte Espiritual del Centro Aletti se encuentra en la sacristía y fue realizado en la campaña de trabajo llevada a cabo en septiembre de 2005, misma que desarrolla un programa iconográfico que realiza una lectura en paralelo de escenas del Antiguo y Nuevo Testamento. Además, teniendo presente la función del espacio, descubrimos que se ha dotado de contenido litúrgico a todas las escenas, inspirándose en los textos de San Ireneo sobre la creación, según los cuales el Padre la realiza a través de sus manos, es decir, el Hijo y el Espíritu Santo, lo cual otorga también un sentido trinitario al conjunto.

El bautismo [Fig. 5], situada entre dos vanos, ocupa todo el espacio disponible desde el zócalo hasta la moldura del techo. En su iconografía sigue la tradición habitual en la Iglesia oriental en la cual se representa a San Juan Bautista, vestido con pieles, inclinado completamente hacia Cristo al cual bautiza con la mano derecha mientras que, con la izquierda señala a lo alto, donde está representada una paloma y la presencia del Padre a través de unos hilos dorados que parece recoger con su mano. Esta presencia divina se continúa en el río Jordán creado mediante grandes teselas de vivos colores azules que desde la parte superior a la inferior van aclarando su tono mientras aumenta la cantidad de teselas doradas y rojas, las cuales parecen rodean al personaje central. La figura de Cristo, barbado y coronado con un nimbo crucífero, está en el centro de la composición, hierático y vestido solamente con un perizonium blanco y dorado. Es el eje principal de la escena creando un axis vertical que conecta el plano terrenal con el celeste, presente también a su derecha a través del ángel que, vestido con una túnica blanca y una estola, se acerca, como diácono, a servir a Cristo. Los tonos de la escena distinguen claramente las dos partes de la composición: a la izquierda tonos terrosos que cubren la ropa del bautista y las montañas representadas a ese lado del Jordán y a la derecha tonos claros y luminosos donde el blanco configura vestiduras y naturaleza. Este cambio en la paleta cromática nos remite también al paso de la antigua ley a la nueva alianza en Cristo que, representado en la parte central, une las dos partes de la composición y de la historia.

Siguiendo la organización del espacio de la sacristía, la iconografía del bautismo hay que leerla en relación con la escena de la creación de las aguas, ubicada frente a ella. La relación está clara, en un primer término, por la referencia de ambas al aspecto acuático, elemento de gran carga teológica que recuerda a la fuente de la vida pero que también se relaciona con la muerte, debido al pasaje del diluvio. Sin 
embargo, para una interpretación más completa, hay que tener presente además las oraciones de preparación para los sacramentos que presentan la creación del mundo como primer paso para la venida de Cristo. Por ello, en este caso la representación del bautismo de Cristo en el Jordán, momento de inicio de su vida pública, pondría en relación la actividad creadora del Padre en el inicio del mundo y la «recreación» llevada a cabo por el Hijo a través de la redención. Esta interpretación también se aplica a otras de las escenas de este espacio, como es la creación de la tierra, los árboles, las plantas y el trigo que tiene enfrente el momento en el que Cristo parte el pan ante los discípulos de Emaús, momento que hace presente como el pan, fruto de la tierra y del trabajo del hombre, se torna a través de la redención de Cristo en el verdadero pan de vida.

Otro de los elementos que relaciona estas dos escenas es la presencia del Espíritu Santo, representado en el bautismo en forma de una paloma que sobrevuela la composición. El espíritu de Dios, que según el Génesis también aleteaba sobre las aguas en el momento de su creación, vuelve a aparecer en el momento de la "recreación» permitiendo que la materia se transforme en materia de sacramento, transformando su significado de muerte en uno de vida eterna. Aunque la base patrística de Tertuliano está clara en esta interpretación, Rupnik también refiere una meditación del teólogo ruso Bulgakov al recordar que "como en la Creación del mundo el Espíritu de Dios aleteaba sobre las aguas, así en el Bautismo de Cristo, el Espíritu descendió sobre Él» (Rupnik y Cervera, 2008, p. 23).
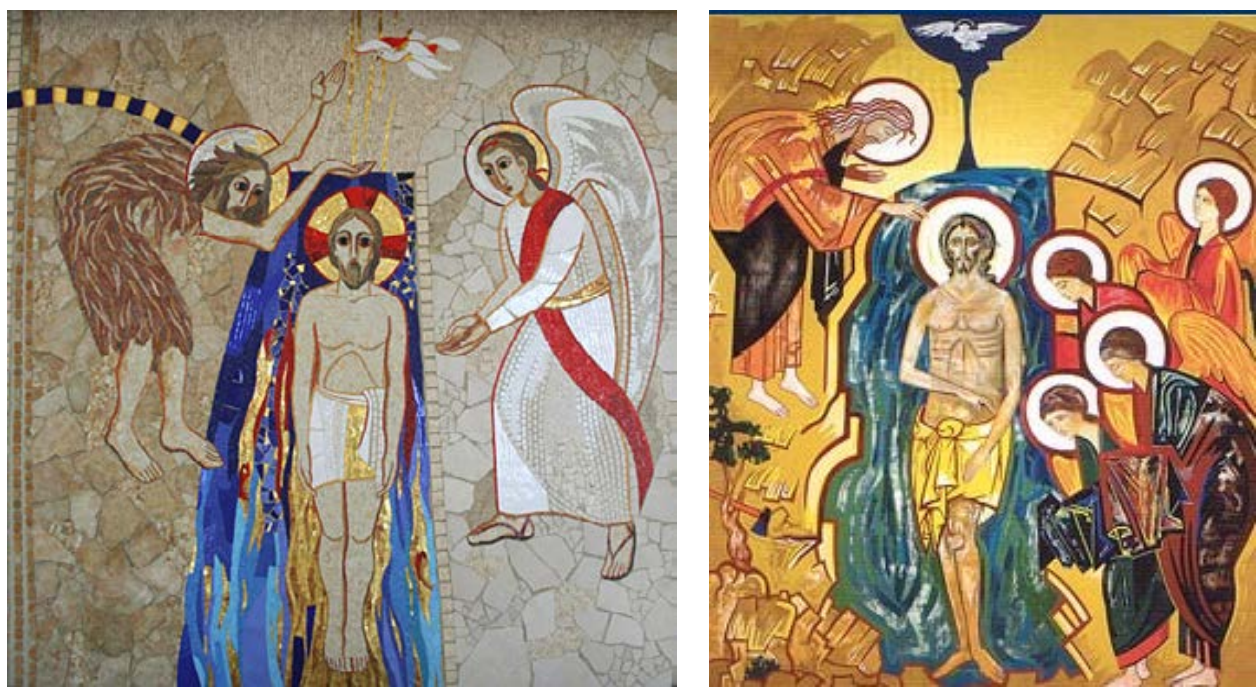

Figs. 5 y 6. Bautismo. Izq.: Rupnik, Sacristía, 2005. Dcha.: Argüello, Ábside. 2004. Catedral de Santa María la Real de la Almudena (Madrid) 
Por su parte, el bautismo de Cristo realizado por Argüello es la primera de las composiciones del ábside y abre la suerte de «corona mistérica> que se desarrolla en el ábside de la catedral. La composición sigue el esquema habitual del autor ${ }^{14} y$ es muy similar a la que hemos visto en Rupnik en cuanto a su iconografía, aunque Argüello la completa con más personajes y con pequeños elementos presentes en la iconografía oriental [Fig. 6]. Una de las diferencias entre ambos artistas es la paleta cromática ya que en el caso del ábside los colores con más ocres y tierras, tanto en los dos bloques de montañas que desde la parte superior configuran el fondo de la composición como en los vestidos de los personajes, de tonos más cálidos que los anteriores. En este caso, Juan aparece vestido con un manto y una túnica, al igual que los ángeles de la parte derecha, tres de los cuales se inclinan hacia Cristo con las manos veladas en señal de respeto. Un cuarto ángel aparece en segundo plano, también con sus manos veladas pero mirando al cielo desde donde baja una paloma con una aureola que está enmarcada por un semicírculo de tono azul. La santificación y recreación del agua que se remarcaba en el caso de la sacristía también está presente en esta composición, pero se representa de forma diversa. En este caso, la presencia divina del cielo se une a la tierra mediante una especie de río o línea azul que parte de la base del semicírculo que contiene a la paloma conectándose con las aguas del Jordán, cuyo tono verdoso se contagia de ese azul mediante trazos de color. Además de este detalle, la santificación de las aguas viene dada principalmente por el gesto bendicente de Cristo que con su mano derecha extendida transforma las aguas de la muerte en el agua de vida del sacramento.

Finalmente, la composición se completa en la esquina inferior izquierda con un pequeño árbol que presenta un hacha en su base y que está relacionado con la misión de Juan. Si en este caso no se representa al bautista con su habitual atuendo de piel de camello al que aluden los evangelios y que nos traslada a su labor profética, se recuerda su ministerio a través de este elemento que remite al evangelio de Mateo, en el que se encuentra una llamada a conversión similar a la realizada por el precursor (Mt 3, 10).

\subsection{Transfiguración}

La escena de la transfiguración, en ambos autores, se basa en el relato evangélico que necesariamente fija los personajes y las líneas fundamentales de la composición. Como ya hemos observado en el caso anterior, la literalidad de la obra de Argüello con respecto a sus fuentes iconográficas orientales,

${ }^{14}$ A lo largo del presente estudio se analizará con mayor profundidad esta iconografía dentro de la producción pictórica de Kiko Argüello, estudiando sus fuentes artísticas y teológicas. En este apartado solamente se busca comparar la obra de los dos autores, ya que ambos utilizan fuentes similares. 
centradas principalmente en el arte ortodoxo ruso y la escuela de Rublev, hace que su composición presente todos los personajes habituales sin realizar innovaciones o concesiones iconográficas, mientras que la obra de Rupnik es mucho más escueta.

El mosaico con la escena de la transfiguración está ubicado dentro de la decoración de la sala capitular, cuyos trabajos se realizaron en octubre de 2006 con la idea de que todo el conjunto reflejase una idea trinitaria, por lo cual esta escena es especialmente adecuada para expresar la presencia de las tres personas, siguiendo para ello la tesis del teólogo Bulgakov (Rupnik y Cervera, 2008). Ocupa el espacio principal de una de las paredes en una composición de tipo triangular que está acogida por unas franjas de mosaico que la separan de la escena del sacrificio de Isaac (Gn 22), en la esquina superior izquierda, y la representación de la profecía de Ezequiel de los huesos secos (Ez 37, 4-6), en el lado contrario.

Cristo es la figura principal de toda la composición y atrae la atención por su ubicación en el eje central de la escena y por su mayor tamaño con respecto a las demás figuras [Fig. 07]. Está de pie, encima del monte Tabor, vestido con una túnica blanca, cíngulo dorado y mando blanco con hilos de oro. Porta en la mano izquierda un rollo cerrado mientras que bendice con la mano derecha. Aparece dentro de una mandorla ovalada con fondo azul y rodeada de teselas doradas que no está completamente cerrada, sino que en algunas zonas parece descomponerse. Esta forma de representación está basada en los textos de Gregorio Palamas que indica que la nube teofánica encierra en su interior la impenetrabilidad del conocimiento de Dios y, por ello, es una mandorla brillante al exterior y oscura al interior. En la historia del icono oriental esta idea ha estado presente y por ello, el círculo interior suele ser de colores oscuros y casi negro, mientras que al exterior son brillantes.

En la parte superior de la mandorla aparecen unas líneas doradas que en su descenso parece que coronan a Cristo, apareciendo también vinculadas con los demás personajes de esta composición mediante la combinación de teselas rojas y doradas que alude simbólicamente a la acción del Espíritu Santo.

Debajo de la figura principal aparecen, en las laderas del monte, los dos testigos de este momento: Moisés, a la derecha portando en sus manos las tablas de la ley, y Elías, a la izquierda vestido con un amplio manto y señalando al Mesías al cual había anunciado mientras sostiene en su mano derecha el rollo de sus profecías. Estos personajes acompañan a la figura central personificando la ley y los profetas cuyos textos convergen y se cumplen en Cristo. 

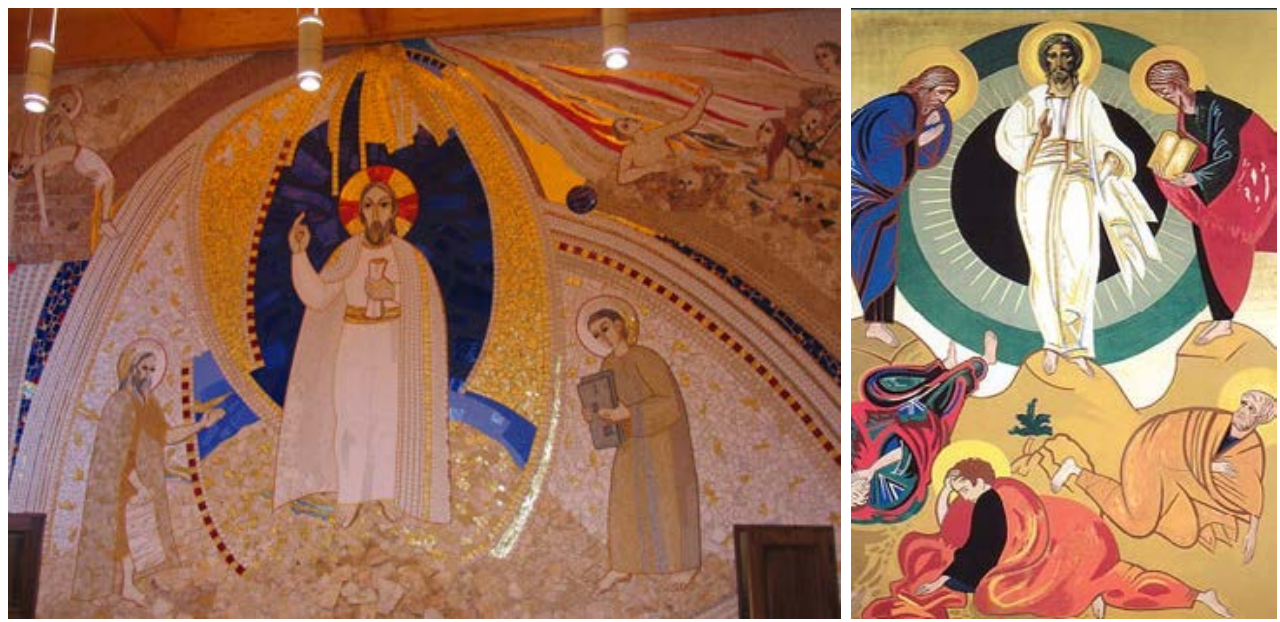

Figs. 7 y 8. Transfiguración. Izq.: Rupnik. Sala Capitular, 2006. Dcha.: Argüello, Ábside, 2004. Catedral de Santa María la Real de la Almudena (Madrid).

En el caso de Argüello, su composición es mucho más clásica ya que se inspira en los iconostasios orientales adaptando su esquema habitual al espacio que proveen los paños del ábside. Por tanto, la composición resulta más estrecha y vertical que en otras de sus obras, sin que esto suponga la eliminación de los personajes clásicos [Fig. 8]. La escena se divide en dos planos: el celeste, en el que están la figura de Cristo, Moisés y Elías, y el terreno, donde están las figuras de los apóstoles, resultando una composición muy equilibrada con tres personajes en ambos partes que aparece, además, ubicados en ejes similares.

La parte superior está dominada por la figura de Cristo, vestido con túnica y manto blanco de pliegues marcados que permiten reconocer el movimiento descendente del personaje. Es una figura que, por el color blanco de sus vestiduras y la presencia de dorados en ellas, anticipa la resurrección, haciendo presente así el momento en el que deja ver su naturaleza humana revestida de la belleza divina. Esa presencia divina está también en la mandorla, compuesta con tres círculos concéntricos que van del verde esmeralda al verde grisáceo y al negro. Este cambio en los colores sigue la interpretación que ya hemos avanzado en el caso de Rupnik. El arte ha representado de esta manera lo insondable del conocimiento de Dios que como un sol de justicia brilla en la parte central, a pesar del color negro. Esta aparente oscuridad se reviste con la esperanza de la revelación y de ahí el tono verde del resto de la mandorla que nos remite, por una parte, a la naturaleza humana que reviste la divinidad de Cristo y, por otra, a la esperanza en la revelación definitiva del Hijo de Dios. Esa revelación ya había sido contemplada por los dos personajes que acompañan a la figura central: Moisés y Elías. Ambos, representantes de la ley y los profetas, en definitiva, de la Antigua Alianza, anunciaron la venida del Mesías y pudieron contemplar la gloria de Dios antes de su revelación al mundo, ya 
que el primero pudo hablar con el Padre y ver su espalda desde la hendidura de la roca $(\text { Ex } 33,18-23)^{15}$ y el segundo fue arrebatado al cielo (2Re 2, 1-13). Cada una de estas figuras están sobre un pequeño montículo, igual que Cristo, lo cual relaciona este momento con la trinidad ya que es un momento teofánico por excelencia en el que el Padre reconoce a su Hijo, el cual cumple su misión por el Espíritu Santo.

El plano inferior de la escena se corresponde con la parte terrenal. En ella, tres de los apóstoles presencian la escena con actitudes distintas. Santiago, a la izquierda inmediatamente debajo de la figura de Elías, cae hacia atrás mientras cubre su rostro con ambas manos. Juan aparece en el centro, debajo de la figura de Cristo, da la espalda a la imagen central mientras intenta cubrirse con el manto, igual que hizo Moisés ante la presencia de Dios en el Sinaí. Finalmente, Pedro, a la derecha de la composición, aparece arrodillado y es el único de los apóstoles que se vuelve para mirar la escena, lo cual concuerda con el relato evangélico ya que al ver esta visión dice a Jesús que quería hacer tres tiendas, una para cada uno de los personajes principales, tiendas que parecen figurarse en los tres pequeños montículos que señalan la presencia divina, igual que la tienda del encuentro lo hacía para el pueblo de Israel durante el camino hacia la tierra prometida, gloria que estos tres apóstoles pudieron ver en el Tabor.

Si la composición de Argüello incluye, como es tradicional, a los tres discípulos en la parte inferior de la composición, el caso de Rupnik los omite en un intento de sugerir que es el propio espectador el que ocupa ese lugar de los apóstoles siendo parte de la escena. Este hecho se remarca con la colocación de la mesa que utilizan los obispos en la parte inferior de la escena, lo cual hace que los prelados madrileños, uniéndose al legado apostólico, ejemplifiquen a todos los bautizados que buscan la contemplación de la gloria de Dios.

\subsection{Crucifixión}

La tercera de las iconografías de este ciclo cristológico es la crucifixión, momento fundamental de la pasión de Cristo lo cual hace que sus representaciones se repitan en múltiples ocasiones en la catedral de Nuestra Señora la Real de la Almudena.

En el caso del artista esloveno, dentro del espacio de la sacristía, se representa a Cristo en la cruz en uno de los frentes, adaptándola al espacio dejado por las puertas de la sacristía. Esta representación está insertada en una iconografía compleja que no solo remite a la crucifixión, sino que también rememora la creación y pentecostés. Siguiendo la petición del arzobispo madrileño, el cual pedía que este espacio remitiera a la creación del mundo y su recreación en Cristo, Rupnik presenta en esta

${ }^{15}$ Es interesante el paralelismo entre la visión que Moisés tiene de Dios cobijado en la hendidura de la roca que Dios protegía mientras que pudo ver su espalda y la contemplación en adoración que tributa al Hijo durante la transfiguración. 
pared las dos manos de Dios Padre, haciéndolas visibles a través de la representación de las otras dos personas de la trinidad: Jesucristo y el Espíritu Santo. Por ello, en esta pared se representa, adaptándolos a los espacios que dejan las puertas de la sala, a Cristo en la cruz y el descenso del Espíritu Santo sobre la Virgen María, ambas escenas cubiertas por una suerte de manto que se mueve sobre ellas y que representa al Padre cuya presencia se deja sentir a través de la acción de las otras dos personas de la Trinidad.

La crucifixión representa solamente a Jesús en la cruz en una escena sencilla que está cubierta por un manto que representa la presencia del Padre [Fig. 9]. La cruz tiene forma arbórea y nos remite al árbol del Edén, representado en la escena de la creación de Adán y Eva, también presente en esta sala, que es transformado de árbol de pecado a un árbol de salvación. En la cruz está crucificado Cristo cubierto únicamente con el paño de pureza y representado con el nimbo crucífero en su cabeza, la cual reclina hacia un lado ya que es una representación de Jesús ya muerto, como se puede ver por la herida del costado de la que mana la sangre e hileras de teselas doradas que vuelven a hacer presente la acción del Espíritu Santo.

La figura de Cristo crucificado, que como hemos visto se representa en la parte izquierda de la composición, extiende su presencia en las escenas de ese lado de la sacristía ya que está presente en las tres escenas desarrolladas entre los vanos, es decir, el bautismo, el encuentro con los discípulos de Emaús y el descenso a los infiernos. La presencia de la mano creadora de Dios en todas las escenas no solo se hace presente a través de la presencia del Hijo, sino que también es visible por la aparición de unas franjas de teselas cuadradas que combinan el color dorado y azul. Se observan primeramente franqueando la escena de Cristo en la cruz y aparecen en todas las demás composiciones sobrevolando las figuras lo cual nos ayuda a relacionar todo el conjunto, expresando, a su vez, esta presencia divina.

A pesar de que la composición de Argüello es, en su cantidad de personajes, más compleja que la de Rupnik sigue reduciendo los participantes al número mínimo exigido por el relato evangélico, apareciendo solamente Cristo, María y Juan, mientras que, en otros iconos orientales, como el icono de la Crucifixión del Taller de Dionisio (c. 1500) conservado en la Galería Tretiakov, aparecen también el centurión Longinos, María Magdalena y las santas mujeres.

Por su parte, Argüello mantiene sus mismas fuentes iconográficas y realiza una escena clásica del calvario con la presencia de Cristo crucificado acompañado del discípulo Juan y la Virgen María [Fig. 10]. Esta escena, tan habitual en el arte cristiano, representa el momento en el que Cristo desde la cruz indica a María como madre de todos los creyentes (Jn 19, 25-27). Por ello María, que aparece como doloroso, extiende las manos hacia su hijo como un signo de acogida de la voluntad de Dios y de Juan, que personifica aquí a todos los cristianos. 

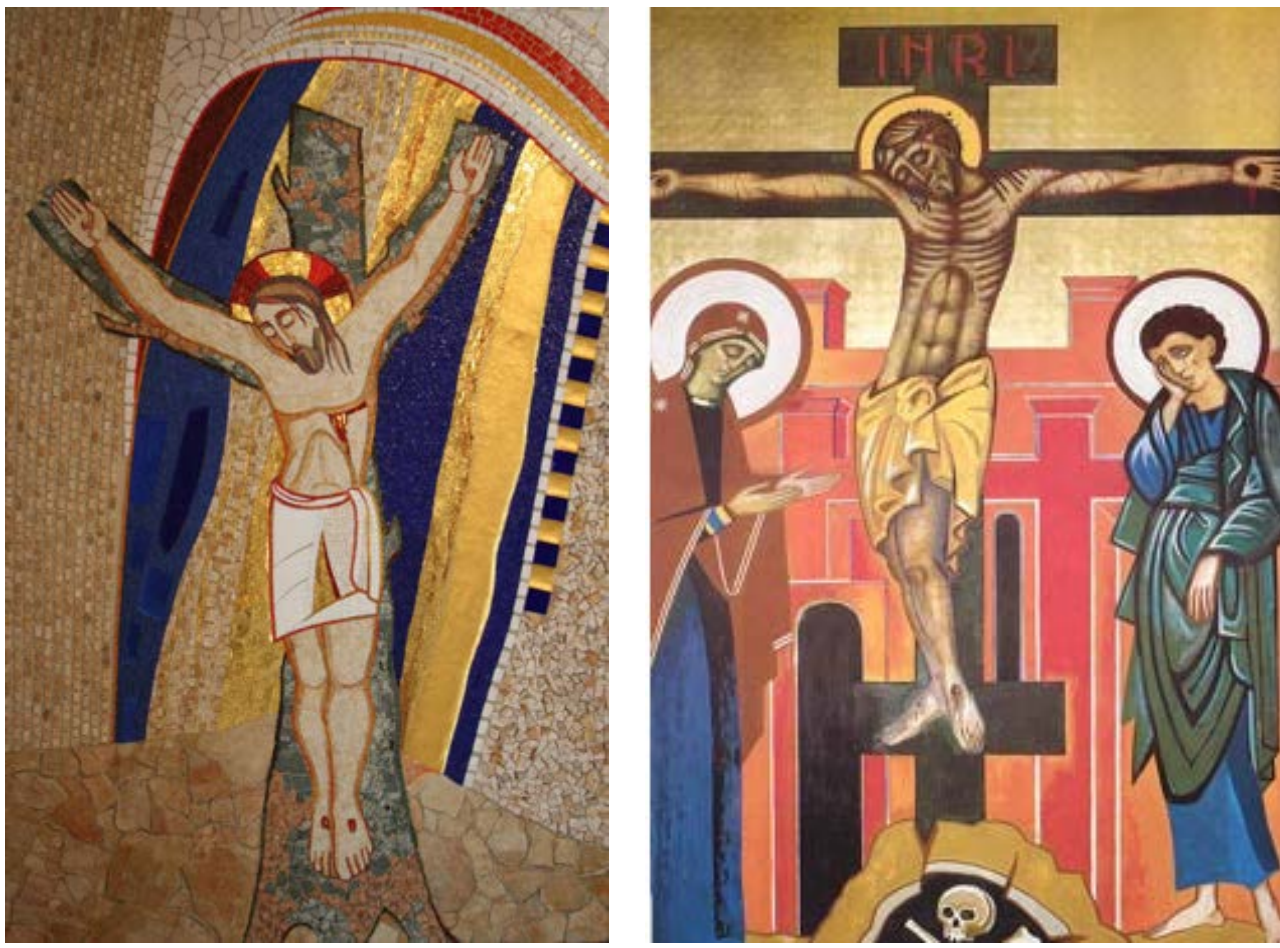

Figs. 9 y10: Crucifixión. Izq.: Rupnik, Sacristía, 2005. Dcha.: Argüello, Ábside, 2004. Catedral de Santa María la Real de la Almudena (Madrid)

El dolor de la madre es compartido por el discípulo que ocupa la parte derecha de la representación. Viste un manto verde y túnica color azul oscuro, color muy relacionado con la divinidad y que en la iconografía visten las personas a las que Dios les transmite su santidad. En el caso de este apóstol, identificado con el escritor del cuarto evangelio, viste este color ya que su evangelio es el que más trata la divinidad del Verbo, lo que se relaciona con el verde de la esperanza, color de la vida sobre la tierra y signo de renovación espiritual y muy propio de aquellos que anuncian a Cristo. Juan sostiene su cabeza en la mano en señal de duelo, sin embargo, a pesar de lo trágico del momento y del dolor que expresan las figuras de María y el discípulo, toda la escena transmite gran serenidad ya que entre las figuras se puede trazar un triángulo que las reúne, símbolo de trinidad y perfección, lo cual da estabilidad a la composición y une a los personajes mediante un juego de miradas.

La figura central de la composición es Cristo crucificado cubierto únicamente con el perizonium, está coronado de espinas y presenta en su cuerpo las huellas de la flagelación. Está clavado en una gran cruz negra con tres clavos, elemento que relaciona esta obra con la tradición occidental a pesar de la fuente influencia de la iconografía ortodoxa. Sobre su cabeza aparece el letrero INRI y bajo sus pies, apoyados en el suppedaneum, está una pequeña caverna con un cráneo y unos 
huesos que la tradición identifica con Adán. Los brazos de Cristo, así como la gran cruz, está realizados exageradamente alargados llegando a cubrir completamente las figuras de María y de Juan, lo cual significa que la redención que brota de este momento abarca a toda la Iglesia, personificada por estas figuras, llegando también a acoger a los gentiles, ya que los brazos se extienden sobre las murallas de Jerusalén, delante de las cuales tiene lugar la escena, cumpliendo así lo que indica el relato evangélico (Mc 15, 20. 22). Esta muralla está formada por un alto muro almenado que presenta dos puertas, una de ellas más estrecha que la otra, que recuerda la parábola de la puerta estrecha por la que se debe pasar para tener la Vida Eterna.

\subsection{Anástasis, Tumba vacía y Resurrección}

Uno de los pasajes que presentan mayor diferencia en cuanto a su representación iconográfica es la resurrección ya que cada uno de los autores elige, para representarla, iconografías diferentes, lo cual nos revela el amplio catálogo de imágenes que han trasladado este pasaje al mundo del arte. En este caso, veremos que para representar la resurrección en el recinto catedralicio madrileño se han utilizado las representaciones de Cristo resucitado, la tumba vacía y la Anástasis o descenso a los infiernos.

Rupnik utiliza la escena de la Anástasis o descenso a los infiernos para representar la resurrección de Cristo [Fig. 11]. Como recoge Santos Otero, esta iconografía se inspira en el texto apócrifo de las Actas de Pilatos que indican que Cristo aparece triunfante rescatando a Adán y Eva del infierno (Santos Otero, 1984, pp. 449-465). Ahondando en esta idea que aporta la clave principal para su lectura, san Efrén el Sirio indica en sus textos que Adán y Eva, que están muertos como consecuencia de su pecado, aparecen como primicia de toda la humanidad que es salvada a través de la redención. Para mantener la dualidad entre creación y «recreación» que expresan todas las escenas de la sacristía de la catedral madrileña, la iconografía de la anástasis que aquí nos ocupa tiene afrontado el momento del pecado original, pasaje que, desde el primer arte cristiano, ha evidenciado la prefiguración de la salvación de Cristo ya que, como podemos ver en la obra de Rupnik, el árbol del paraíso, origen del pecado, se convierte en la cruz en el lugar de la salvación. Los primeros padres se representan en actitud muy distinta a la escena de la anástasis. A pesar de la desnudez cubierta por vegetación que exige el relato del Génesis vemos cómo, en este caso, son ellos mismos los que extienden sus manos hacia el fruto prohibido mientras que después es Jesús el que agarra sus manos suplicantes para sacaros de la muerte.

En esta composición destaca la figura de Cristo nimbada, que imprime gran movimiento a la composición a través del movimiento de los vestidos blanco, evidenciando así el acto de descender. Lleva consigo la cruz de su muerte, que ha colo- 
cado en las fauces del monstruo Leviatán que había engullido a los pecadores, para mantenerlas abiertas mientras que rompe con ella la muerte, lo cual se puede ver por la gran mancha negra que parece descomponerse en pequeñas teselas que van saliendo de la boca del monstruo. Cristo se agacha para sacar a Adán y Eva, primeras criaturas que personifican a toda la humanidad, una idea que concuerda con la exhortación paulina (1Co 15, 21s). Adán, vestido con una túnica verde, mira directamente a Jesús, que agarra su mano llevándola hasta su costado, mientras que con la otra mano agarra a Eva, cubierta por un manto y túnica de colores terrosos que, con sus ojos cerrados, reclina su cara sobre la llaga de Cristo.

Aunque el tema es el mismo entre los dos autores que nos ocupan, el tratamiento no es similar ya que Argüello sigue el modelo de representación que no incluye la presencia del Leviatán, por lo que el infierno aparece representado por una gruta u oquedad cuyas puertas son rotas por el descenso de Cristo que saca a Adán y Eva de sus tumbas. Esta representación es un eco de obras tan conocidas como la anástasis del Paracclesión de San Salvador en Chora (s. XIV) en Estambul, composición también presente en iconos griegos de Tesalónica, Dafni y la escuela de Creta, así como en iconos rusos que presentan una distribución similar, como puede advertirse en el Descenso a los infiernos de la escuela de Novgorod (segunda mitad del siglo xv); el Descenso al limbo del taller de Dionisio (1502-1503) o los mosaicos del nártex del monasterio de Hosios Loukas en Grecia.
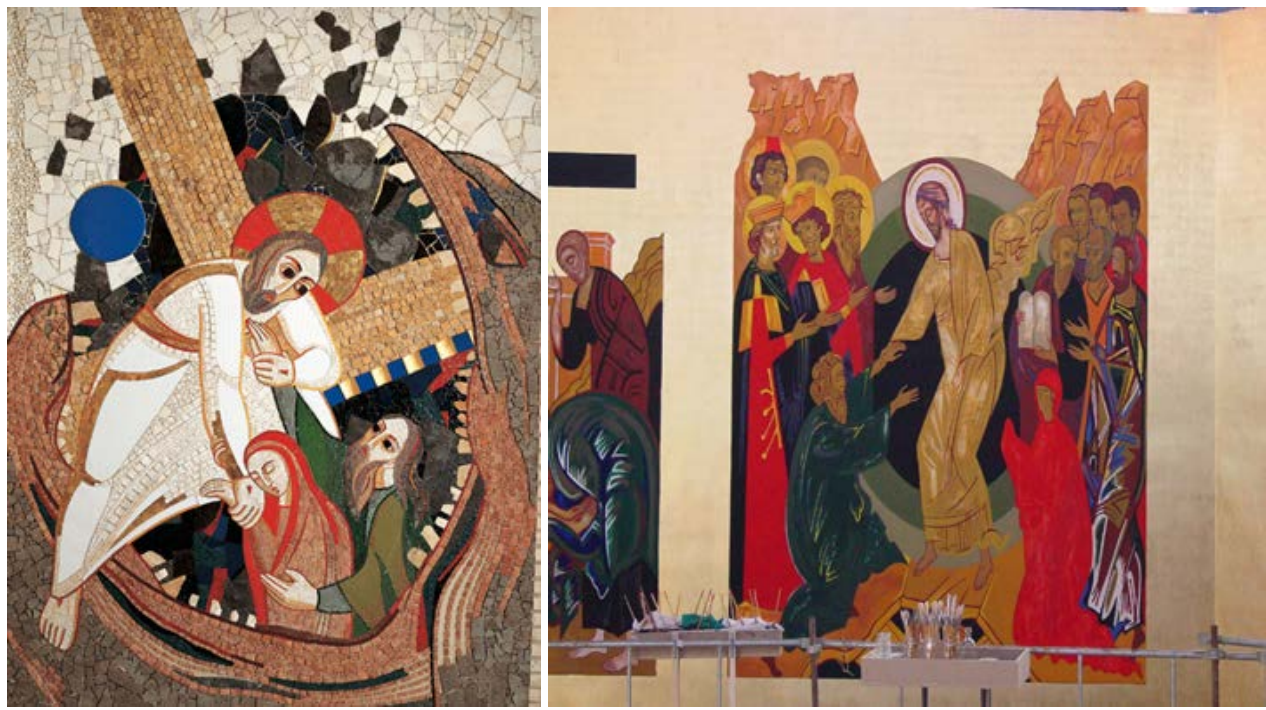

Figs. 11 y 12: Descenso a los infiernos. Izq.: Rupnik, Sacristía, 2005. Catedral de Santa María la Real de la Almudena (Madrid). Dcha.: Argüello, Corona mistérica, (2003), Iglesia Santa Catalina Labouré (Madrid). 
Para su representación de la resurrección de Cristo, Argüello elige en la catedral madrileña dos iconografías diferentes que conviven en su intervención en el ábside central. Por un lado, está el icono de la tumba vacía [Fig. 13] y, por otro, la vidriera que representa a Cristo resucitado [Fig. 14].

En los lienzos del ábside se representa la escena conocida como la tumba vacía siguiendo para su creación una conocida obra del taller de Rublev datada en la primera mitad del siglo XV conservada en la catedral de la Trinidad en Sergiev Posad. Se trata de la traslación en imágenes del momento en el cual las santas mujeres acuden al sepulcro y se encuentran con el ángel que les anuncia la resurrección. Siguiendo fielmente el relato evangélico (Mt 28, 1-8; Mc 16, 1-8; Lc, 1-10; Jn, 1-2), las mujeres, identificadas por Marcos como María Magdalena, en primer término, con una aureola sobre su cabeza, María la de Santiago y Salomé, acuden al sepulcro con aromas para embalsamar el cuerpo de Jesús que llevan en sus manos. Su gesto es apesadumbrado y miran cabizbajas la tumba vacía que ocupa la parte central de la composición. Es un gran sepulcro de color negro sobre el que destacan las vendas y el sudario y que recuerdan a la representación del pesebre en los iconos de la Natividad y al Jordán en la escena del Bautismo, lo cual crea un hilo conductor entre las escenas significando el cumplimiento de la misión de Jesús. La tumba parece salir de una gran oquedad, el sepulcro que estaba cubierto con una gran piedra redonda sobre la que está sentado el ángel, el cual ocupa toda la parte derecha de la composición. Es una gran figura vestida de blanco y dorado que trae a la escena la luz de la resurrección. Este mensajero mira directamente a las mujeres y se dirige a ellas para señalarles que Jesús ya no está en el sepulcro en el que ellas lo buscaban, encargándoles también el anuncio a los discípulos. Toda la escena tiene lugar en un terreno agreste en el que destacan dos montes entre los que está ubicado el sepulcro vacío, simbolizando con esta dualidad el paso de la muerte a la vida y el paso de la Antigua Alianza al Nuevo Testamento, todo ello gracias a Cristo que, a pesar de su ausencia, es el punto central de la composición, al cual se refieren todas las figuras.

La figura de Cristo resucitado, ausente en la escena de la tumba vacía, se revela como centro y clave interpretativa de toda la composición en su representación en la vidriera de la capilla central de la girola. En ella Cristo sale de la tumba ante el estupor de los soldados que caen en tierra. Esta representación es mucho más cercana a la iconografía occidental y existen muchos ejemplos de ella en el arte español ${ }^{16}$, sin embargo, en el mundo del icono oriental no es habitual, si se buscan las

${ }^{16}$ Los ejemplos son muy números en todas las épocas del arte europeo. Por citar algunos ejemplos de procedencia y épocas diversas, remitimos a las siguientes obras del ámbito europeo: La Resurrección de Jesús de Piero della Francesca (1463); La resurrección de Jesucristo de Rafael (1499-1502); La resurrección de Cristo de Lucas Cranach (1558); La Resurrección de Cristo de Rubens (1611-1612). También en el arte español existen ejemplos reseñables, destacamos únicamente La resurrección de El Greco (1595-1600) o la Resurrección de Cristo de Juan Bautista Maíno (1612-1614). Es este tipo de representación el que más ha influido en el arte religioso 
fuentes de autores clásicos como Rublev o la escuela de Novgorod alejándose del influjo del arte occidental que sufrió el icono ruso a partir del siglo XVIII. Esta combinación en sus fuentes de inspiración habla del conocimiento que Argüello tiene del icono oriental, pero también demuestra su conocimiento de la tradición occidental $\mathrm{y}$ las vanguardias del siglo $\mathrm{xx}$.
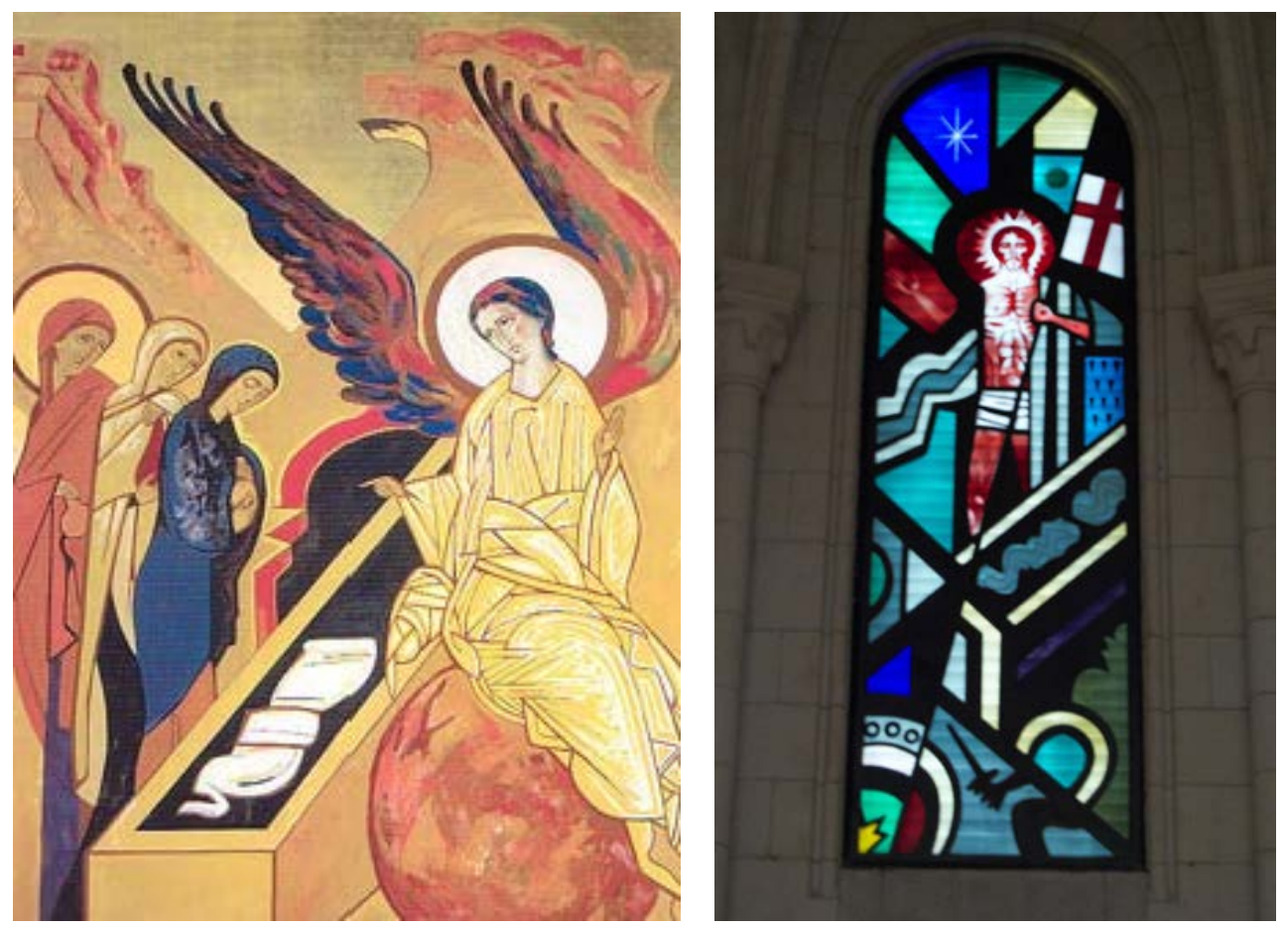

Fig. 13 y 14: Izq.: Argüello, Tumba Vacía, Ábside, 2004. Dcha.: Resurrección, vidriera, capilla central de la girola, 2004. Catedral de Santa María la Real de la Almudena (Madrid).

Al igual que las situadas en lo alto de la girola, esta vidriera está realizada en Murano (Italia) con una técnica en la cual los cristales se engarzan en estructuras de aluminio de color negro. En este caso, el cristal placado a fuego está grabado con ácido clorhídrico para realizar el dibujo del cuerpo de Cristo. La figuración y gran realismo de esta figura contrasta con el resto de la composición en la cual impera una abstracción que nos recuerda claramente a Mondrian por su contraposición de colores divididos por líneas de color negro. En este caso, el contraste entre abstracción y figuración identifica a los personajes de la composición. En la base de la

contemporáneo, produciendo obras como el Cristo resucitado de Andrés García Ibáñez (1999) o las obras del proyecto In Apocalypsin XXI de Francisco Campos. 
escena se representa a los soldados de una forma muy esquemática, se intuyen las formas de los escudos y una espada que claramente destaca sobre el fondo gris, pero no se ven sus rostros ni las figuras completas, que parecen diluirse en un fondo más oscuro que se funde son el sepulcro vacío en el cual están las vendas y el sudario. Sobre estas formas muy geométricas y esquemáticas, destaca la figura de Cristo, mucho más luminosa y realista, gracias a la técnica de grabado empleada. Es una representación habitual de Cristo resucitado que posta un estandarte que cruza en diagonal toda la composición, significando con ello el poder de la resurrección sobre toda la escena a la cual parece llegar por este medio la cruz roja que campea sobre el estandarte blanco. Cristo está de pie, con una estola sobre su hombre que, detrás de él, pare ondear al viento, mostrando con ello el ímpetu y fuerza de la resurrección. Muestra sus manos y costado con los signos de la pasión y su cabeza tiene una aureola en forma de sol, que cristianiza las representaciones de Apolo y el Sol Invictus pagano. En la parte superior aparecen la luna y las estrellas como recordando con ello que la noche fueron los testigos de la hora en que Cristo resucitó, tal y como canta el pregón pascual. La creación es testigo del momento en que Jesús sale del sepulcro y la presencia de la estrella nos trae a la memoria al astro que guía a los reyes de Oriente hasta el niño, uniendo de nuevo la natividad y la resurrección, como queriendo hacer resonar las palabras de Cristo ante Pilato: «para esto he nacido y para esto he venido al mundo» (Jn 18, 37).

\subsection{Pentecostés}

Ya que en el momento de analizar la crucifixión de Rupnik en la sacristía nos hemos referido a la presencia del Espíritu Santo y su representación en ese espacio y dado que Argüello incluye la escena de pentecostés en el ábside de la catedral, vamos a analizar también cómo ambos autores representan este pasaje.

La representación que Rupnik hace de la escena de Pentecostés no es nada convencional ya que no sigue una iconografía habitual con la presencia del colegio apostólico y las conocidas lenguas de fuego, cuyas representaciones son una traslación del pasaje evangélico. Lo que hace este artista es representar solamente a la Virgen María, a la que identifica como pneumatófora, es decir, como portadora del Espíritu Santo. Aparece sobre un terreno pedregoso que parece abrirse y justo en el lugar donde está colocada María hay brotes bajo sus pies que son fruto de la fecundidad del Espíritu [Fig. 15]. Ella aparece con las manos abiertas en una postura orante muy habitual en el cristianismo primitivo ${ }^{17}$. Está vestida con una túnica azul

17 Esta iconografía orante también ha sido utilizada por Argüello, el cual, siguiendo la influencia del arte de las catacumbas, la retoma en algunas de sus obras de los años 80 . Es interesante ver cómo esta influencia dio lugar a un grupo de obras ubicada en el Centro Neocatecumenal Diocesano de Madrid en el que se representa no solo una orante siguiendo esta tipología cristiana primitiva, sino también un banquete y al profeta Jonás. 
y un manto ojo en el que se dibujan tres estrellas y mira directamente al espectador mientras que del cielo descienden lenguas de fuego que destacan sobre un fondo dorado, las cuales harían presente a los apóstoles presentes en la escena habitual. Además, la presencia de María, figura de la toda la Iglesia, personificaría también a todo el colegio apostólico.

Al igual que ya hemos señalado con la figura de crucifixión, la presencia del Espíritu Santo también se extiende a otras escenas de esta sacristía. Si bien es cierto que podría rastrearse en todas las escenas de esta sacristía, es particularmente evidente la relación del Espíritu Santo con los pasajes que se ubican en la parte derecha de la sala. Así, la efusión de Espíritu que cubre a María se continúa por toda la pared haciéndose presente en las escenas de la creación de las aguas y los peces, la creación de la tierra, los árboles, las plantas y el trigo y, finalmente, la creación de Adán y Eva. Esta relación de todas las escenas no solo parte de la interpretación iconográfica, sino que también se hace evidente mediante una franja de teselas cuadradas rojas y doradas que flanquea la figura de la virgen en la pared del fondo para después sobrevolar y atravesar las demás escenas, haciendo evidente esa presencia de la mano creadora de Dios y del Espíritu Santo en todas ellas.
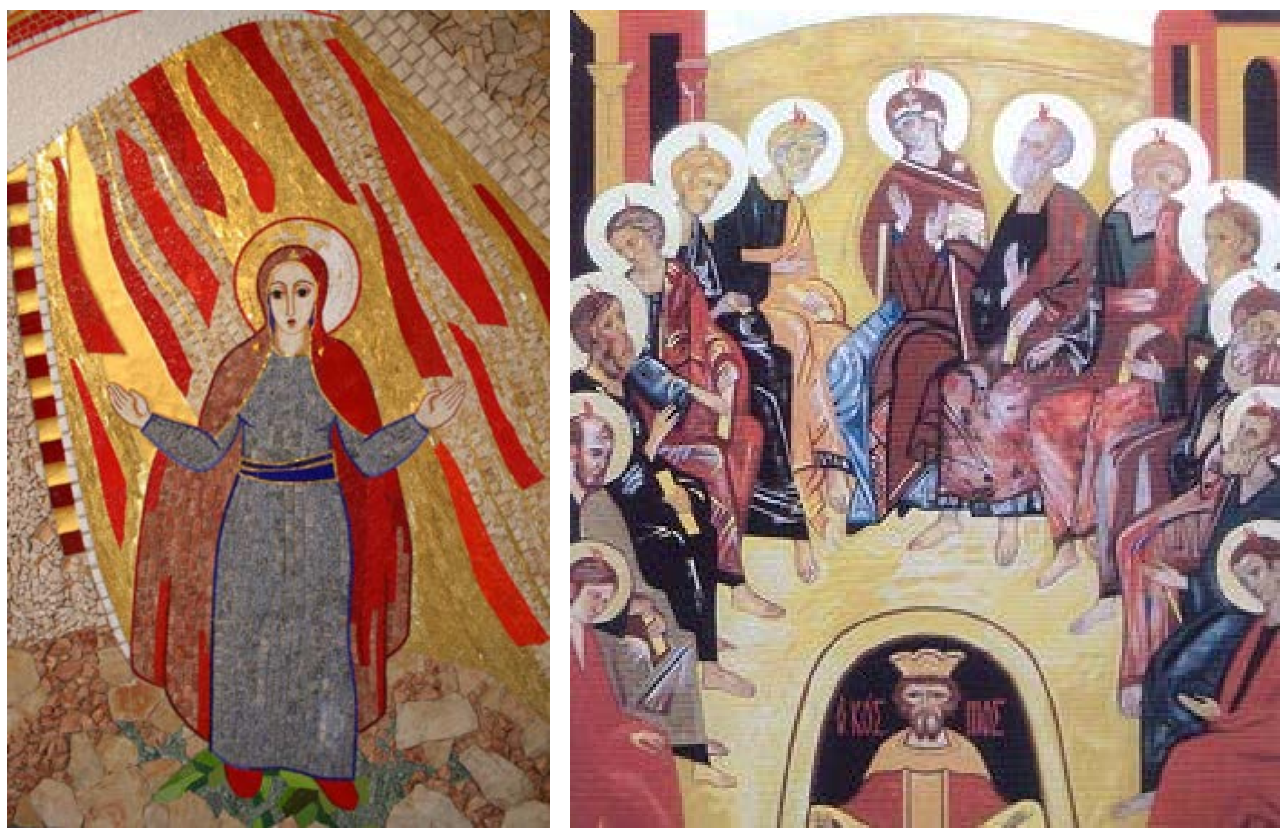

Fig. 15 y 16: Pentecostés. Izq.: Rupnik, El Espíritu desciende sobre la Madre de Dios, Sacristía, 2005. Catedral de Santa María la Real de la Almudena (Madrid). Dcha: Argüello, Pentecostés. Argüello, 2004. Iglesia de Santa Catalina Labouré (Madrid). 
Por su parte, el pentecostés de Argüello es más fiel a los cánones iconográficos ya que incluye los personajes a los que alude el relato de los Hechos de los Apóstoles (2,1-4). Así, los elementos fundamentales del icono son los 12 apóstoles que aparecen sentados en un sitial semicircular [Fig. 16]. Esta representación se permite la licencia de colocar a Pablo en el lugar que dejo vacío Judas en reconocimiento a su importancia entre los discípulos. Todos los apóstoles visten manto y túnica de colores diversos lo que da dinamismo a la escena y portan en sus manos un rollo, símbolo de la predicación. Sobre sus cabezas aparecen las llamas del espíritu, unas pequeñas lenguas de fuego.

A diferencia de Rupnik, el cual coloca a la Virgen peneumatófora en un entorno natural, aquí la escena se desarrolla en el interior de una estancia, como se puede ver por la presencia de dos edificaciones en las esquinas superiores que, unidas por un arco, enmarcan toda la composición. Sin embargo, el hecho de que los personajes se sitúen en un hemiciclo abierto hacia el espectador y el uso de la perspectiva invertida ayudan a introducir a este en la escena representada y lo hace partícipe también de la efusión del Espíritu.

En el eje central de la composición se coloca a la Virgen, flanqueada por Pedro, a su derecha, y Pablo a su izquierda. Está sentada, con las manos abiertas aceptando el don que recibe, en una postura similar a la que presenta en los iconos de la anunciación, lo cual relaciona estos dos momentos en los cuales la acción del Espíritu Santo se hace especialmente presente. María no siempre aparece en el centro del colegio apostólico en los iconos de pentecostés y su presencia es fruto del auge del culto mariano, aunque es más habitual en el arte cristiano occidental que en la iconografía bizantina ${ }^{18}$.

Finalmente, el último de los personajes representados es muy propio de la iconografía oriental. Se trata de un personaje barbado y coronado colocado en una herradura que limita un espacio negro. Esta representación parece un rey que por su indumentaria puede recordar al basileus bizantino y porta en sus manos un paño en el que se aprecian ligeramente doce rollos, símbolo de la predicación de los apóstoles, labor que ellos aceptan al llevarlos en sus manos. Esta representación también pone de relieve la acción del espíritu en la vida del mundo y de la Iglesia. Al igual que vimos en el caso de Rupnik cómo el paráclito estaba presente en las escenas del Antiguo Testamento representadas en la sacristía aquí se evidencia la acción del Espíritu a través de la vida de la Iglesia. El cosmos, encerrado en un espacio oscuro, representa al mundo que parece encerrado esperando la predicación de

${ }^{18}$ Aunque la presencia de María en este pasaje no aparece aclarada en el relato apostólico, se supone que estaría presente en la enseñanza de los apóstoles y en la fracción del pan y en la oración (cf. Hch 2, 42). Su presencia, más que estar relacionada con el recibimiento de este don, hay que leer en relación con la vida de la Iglesia primitiva, para la cual María, recibida desde la cruz en casa de Juan (cf. Jn 19, 25-27), era un pilar fundamental. 
los apóstoles, los cuales, a través de su predicación simbolizada en los rollos, llegan a todos los confines de la tierra.

\subsection{Ascensión}

Otro de los pasajes que ambos autores han realizado es el relativo a la ascensión. En el caso de la catedral madrileña, solamente Argüello ha trabajado este tema mientras que no se encuentran muchos ejemplos en la obra de Rupnik donde se trate esta iconografía de forma única. A pesar de ello, la comparativa de algunas obras de estos autores nos siguen vinculando su producción. Ya que, si bien es la obra de Argüello la que nos ofrece una visión más clara y fiel a la tradición oriental de la iconografía, también en Rupnik tenemos composiciones donde se nos propone este tema a partir de su fusión con otros pasajes.

Para su representación de la ascensión, Kiko Argüello parte de las coronas mistéricas ya realizadas anteriormente, adaptando la composición al panel disponible en el ábside [Fig. 17], lo cual tiene como resultado que las figuras se junten en una composición más abigarrada. Como fuente de inspiración para esta iconografía los artistas cuentan con algunos pasajes del Nuevo Testamento donde se narra que este acontecimiento tuvo lugar en presencia de los apóstoles que miraban al cielo mientras que Cristo se elevaba (Mc 16, 19s; Lc 24, 50-53; Hch 1, 6-14). La iconografía utilizada recoge la tradición iniciada en el siglo IV que divide la composición en dos partes: la inferior con el grupo de los apóstoles con la Virgen María y dos ángeles y en la parte superior Cristo que es Ilevado al cielo. En el mundo oriental se mantienen este mismo esquema como podemos ver en obras tan conocidas como el icono de la Ascensión de Cristo atribuido a Andrei Rublev o su círculo que se conserva en la galería Tretyakov de Moscú, el cual, sin lugar a duda es fuente de inspiración para la obra de Argüello ${ }^{19}$. En la parte superior de la composición aparece el plano celeste en el que Cristo asciende en una mandorla que es sujetada por dos ángeles. Aparece nimbado, vestido con una túnica y manto dorado que se refiere a su entrada en la gloria, mientras que bendice con la mano derecha y sostiene un rollo en la izquierda. Al igual que los iconos orientales, la mandorla que lo rodea está formada por tres círculos que van desde el negro en la parte interior al verde en el exterior, refiriendo este último al próximo envío del Espíritu Santo [Fig. 18].

19 Aunque citamos la obra de Rublev como fuente principal de inspiración, son muchos los iconos que repiten este esquema. Por poner algún ejemplo más citamos: la ascensión del Salterio Khludov; la miniatura del Evangeliario de Moghini conservado en la Galeria de Arte de Matenadaran (s. XII); el icono conservado en el monasterio de Decani (s. XVI) o la cúpula de la iglesia de Santa Sofía de Salónica (c. 843-880/885). 

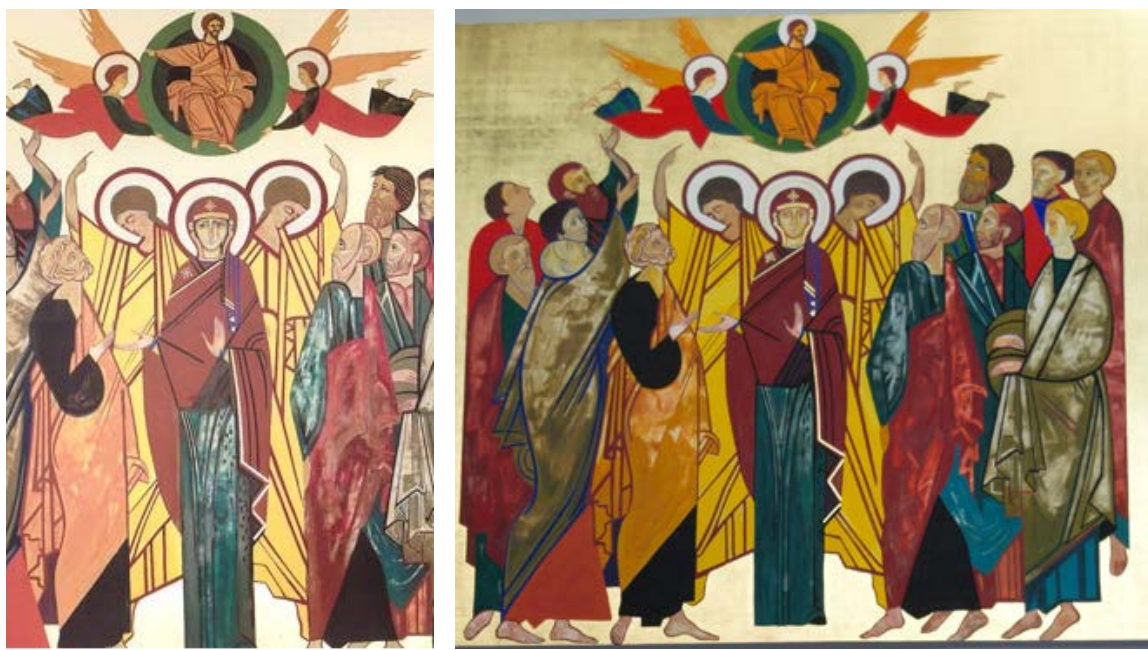

Figs. 17 y 18: Kiko Argüello, Ascensión. Izq.: Ascensión, 2004. Catedral de Santa María la Real de la Almudena (Madrid). Dcha.: Ascensión, 2011. Parroquia Nuestra Señora del Pilar (Valdemoro, Madrid)

Debajo de él, ya en el plano terreno y siguiendo el eje vertical de la composición aparece la Virgen María cuya presencia, aunque no está referida en los textos bíblicos, es habitual en la iconografía. Su figura, vestida con túnica azul y manto rojo ribeteado en dorado, es de gran tamaño en comparación con los discípulos, y separa los grupos de los apóstoles, situados a ambos lados. Tras ella, dos ángeles señalan al cielo, invitando al espectador a dirigir su mirada a la figura de Cristo, pero siguiendo el relato evangélico también urgen a los apóstoles a realizar su misión. Encabezando los dos grupos de apóstoles aparecen Pedro, a la izquierda de la composición, y Pablo, a la derecha, que junto a Juan son las únicas figuras identificables. En todos los rostros se puede ver un gesto triste similar al que tiene la Virgen que, aunque está llorando, transmite igualmente serenidad.

Si comparamos esta composición con la obra de Rublev vemos que sigue una línea clásica que divide la composición en dos planos, terrenal y celeste, siguiendo la tradición no solo del icono sino del arte cristiano en general, en el cual se ha representado este pasaje de la misma manera, como podemos ver, por poner solo algunos ejemplos, en el marfil bizantino con la escena de la Ascensión conservado en el Metropolitan de Nueva York (720-790), los relieves del claustro de Silos, la capilla Scrovegni de Giotto (1304-1313), La Ascensión de Pietro Peruggino (1496-1500) o la Ascensión de Rembrandt (1636).

En el caso de la producción de Rupnik, si rastreamos su obra en busca de representaciones de la ascensión, puede resultar una labor ardua ya que, como hemos indicado anteriormente sorprendentemente no ha trabajado mucho esta iconografía. En el caso de la Capilla Redemptoris Mater, que ya hemos analizado en este capítulo, podemos ver cómo ha fusionado la escena de la ascensión con pentecostés a través de una composición que, si bien repite el esquema del icono de la ascensión 
en dos planos y con María en el centro rodeada de los apóstoles, está representando la venida del Espíritu Santo como puede verse por las lenguas de fuego que están sobre la cabeza de los discípulos.

Solamente hemos encontrado un ejemplo en toda su obra donde se represente claramente la ascensión de Jesús, a pesar de que también se alude a pentecostés por la aparición de pequeñas lenguas de fuego que, por no estar sobre los apóstoles sino preparadas, como esperando el momento de la efusión, nos permiten asumir que todavía se trata de la ascensión. Se trata de la iglesia ortodoxa de la Transfiguración en Cluj (Rumanía, 2006). Para poder leer mejor la escena remitimos a la composición creada más abajo donde su unen todos los personajes ya que en esta iglesia la escena se divide en tres espacios diferentes a lo largo del primer tramo de la capilla mayor, tras el cual se coloca el iconostasio cerrando así el ábside a la manera ortodoxa.

En la bóveda se ubica a Cristo que asciende al cielo dentro de una mandorla marcada en el fondo dorado con pequeñas teselas que van abriéndose para convertir el círculo en una espiral que llega hasta la paloma del Espíritu que está sobre su cabeza. La figura de Cristo parece representar un pantocrátor a pesar de estar incluida en la escena de la ascensión. Está sentado, vistiendo manto túnica blanca y manto dorado, mientras bendice con su mano derecha extendida y sostiene un rollo en la izquierda. A los lados de su cabeza, que tienen el nimbo crucífero, está una inscripción habitual en el icono oriental que suele identificar escenas y personajes, añadiendo en este caso IX CX. Este hecho no es común en la obra de Rupnik y tampoco en la recuperación del icono en el mundo occidental pero aquí obedece más al hecho de que se trate de un templo ortodoxo, por lo cual se mantienen algunas de las características más puras del mundo oriental ${ }^{20}$. A los lados dos ángeles miran a la figura de Cristo mientras sostienen esta mandorla que parece desintegrarse para unirse a la gloria celeste.

Los apóstoles, se dividen en dos grupos, cada uno a un lado de la capilla. Junto a ellos aparecen dos ángeles que señalan al cielo siguiendo la iconografía habitual. Pedro, junto a María, y Pablo encabezan los grupos de los apóstoles, algunos de ellos representados con las manos extendidas como esperando a recibir el espíritu que parece ya preparado. Para relacionar estas figuras de la parte inferior con la esfera celestes se ha utilizado el recurso de realizar bandas verticales que siguen el movimiento ascensional del arco y que conducen la mirada del espectador, junto con la de las figuras, a la parte superior, que combinan los dorados de la divinidad y los ángeles con los tonos tierra de la parte inferior uniendo así estas dos realidades.

${ }^{20}$ Igualmente, dentro de su trabajo en el ajuar litúrgico y al igual que en otros casos se encargan de la realización del sagrario o el altar, en este templo el taller del Centro Aletti se encarga de realizar el iconostasio, pieza importantísima en la distribución del espacio de los templos ortodoxo. 


\subsection{Pantocrátor}

Finalizamos esta comparativa de las iconografías tratadas por ambos autores en la catedral de Nuestra Señora la Real de la Almudena con el pantocrátor, iconografía que, por su contenido escatológico, sirve de cierre al ciclo iconográfico. Aunque Rupnik no ha realizado un pantocrátor en la sede madrileña si podemos observar un ejemplo de esta iconografía en la capital española, dentro de la decoración de la capilla de la Universidad CEU San Pablo [Fig. 19], por lo cual utilizaremos principalmente ese ejemplo para la comparación con el pantocrátor que coloca Argüello como iconografía central en el ábside catedralicio.

Si tenemos en cuenta que la elección de temas iconográficos para los paneles del presbiterio de la seo madrileña busca ser un eco en imágenes de muerte y resurrección de Jesús, la colocación de este icono en el eje central de todo el conjunto nos da la clave de lectura de toda la composición ya que hacia él convergen los otros siete cuadros de la corono mistérica de la Almudena [Fig. 20]. Así, a través de un camino por los hitos principales de la vida de Cristo que finaliza en el pantocrátor, se expresa la espera escatológica de la asamblea cristiana guiando la mirada del fiel hacia la liturgia terrestre, meta de la terrena.

Dentro de la obra de Argüello, el pantocrátor aparece representado en solitario, como en San Bartolomeo in Tuto en Scandicci (Italia, 1998) o la parroquia de Nuestra Señora del Pilar en Valdemoro (Madrid, 2011), o como parte de una escena más amplia de la deesis en la que María y Juan aparecen intercediendo ante la figura de Cristo acompañadas o no por otras figuras, como podemos ver en la parroquia de Santa Catalina Labouré (Madrid, 2004) o la iglesia de la Santísima Trinidad en Piacenza (Italia, 2000). En este caso, debido seguramente a las dimensiones de los paños del ábside, se representa únicamente la figura de Cristo llegando incluso a recortar la mandorla que lo rodea adaptándola al espacio disponible. La composición representa a Cristo en majestad vestido con túnica y manto blanco, color de la resurrección, lleno de pequeños destellos dorados que dan luz a la imagen, señalando la presencia divina. Bendice con su mano derecha mientras que con la izquierda sostiene, abierto, el libro de la vida. Cada una de las partes de este libro presenta una frase evangélica que resume la predicación de Cristo ("Amad a vuestros enemigos», Mt 5,44 ) e invita a la espera de la segunda venida («Vengo pronto», Ap. 22, 30).

Está sentado en un trono formado por la propia mandorla en la que se inscribe la cual está formada por tres círculos concéntricos de color azul oscuro el exterior, negro el intermedio y azul brillante el central. Son las esferas cósmicas que representan, desde dentro hacia fuera, la tierra, la muerte y el cielo y que están atravesados por Cristo que los divide y a la vez los une indicando su paso y presencia en todos ellos. Además, en las esquinas de la composición se atisban cuatro triángulos de color rojo que son la representación de los cuatro evange- 
listas ${ }^{21}$ que han llevado la noticia de la resurrección y la vida en Cristo a todo el mundo.

En el caso de Rupnik tenemos que trasladarnos a otra de sus obras madrileñas para contemplar una representación del pantocrátor ya que en la sede catedralicia no trata esta iconografía. Sin embargo, el ábside de la capilla de la Universidad CEU San Pablo presenta esta iconografía realizada durante una intervención concentrada especialmente en el ábside y presbiterio. Así, las prefiguraciones de cristológicas que presenta la decoración del altar encuentran su finalización en el pantocrátor que ocupa la parte superior del ábside, completada con la representación de María con el niño en la zona intermedia y el descenso de la cruz en la parte inferior derecha. La representación de Rupnik es clásica en su reflejo de las características básicas del pantocrátor que presenta a un Jesús resucitado con vestiduras blancas o doradas el cual aparece dentro de un clípeo bendiciendo con su mano derecha mientras que sostiene el libro abierto en la mano izquierda. Como indica María Rodríguez Velasco, una de las innovaciones que introduce Rupnik es el texto que aparece escrito en el libro, el cual está tomado de una de las cartas de San Pablo, remarcando así la relación entre la iconografía y la sede en la que se encuentra (2014; 101-102). En las primeras representaciones que el artista esloveno hace del pantocrátor, el libro aparece cerrado mostrando una cruz en el frente, tomando como fuente de inspiración una corriente iconográfica que así lo representa, como puede verse en obras como el pantocrátor de Dafni (Grecia, 1080-1100).
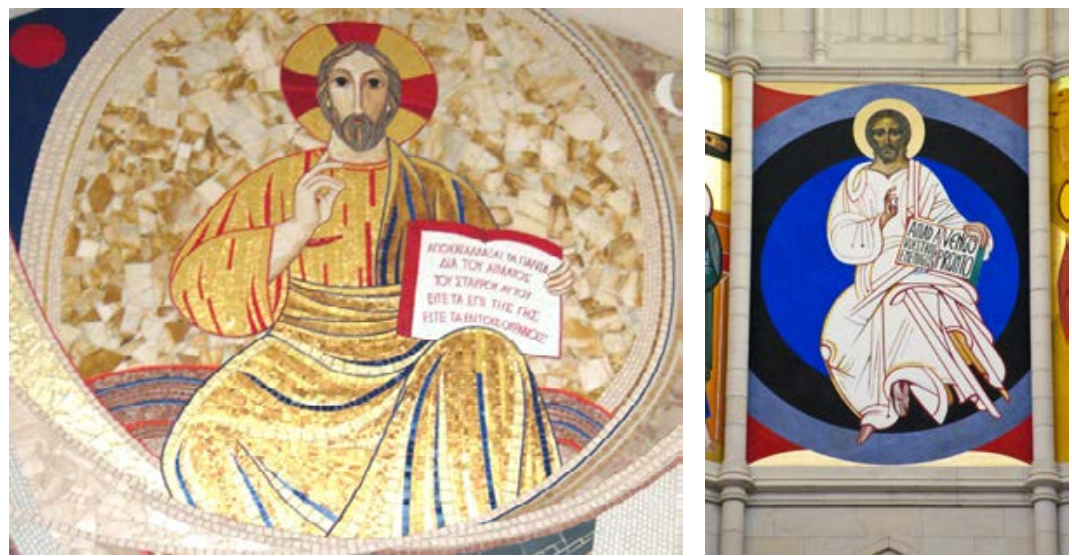

Figs. 19 y 20. Pantocrátor. Izq.: Rupnik. 2009, Capilla de la Universidad CEU San Pablo (Madrid). Dcha.: Argüello. Ábside. 2004. Catedral de Santa María la Real de la Almudena (Madrid).

${ }^{21}$ La presencia de los evangelistas se sugiere aquí únicamente por estas formas rojizas que ocupan las esquinas de la representación muy habituales en el icono oriental, aunque no es raro que en muchas obras medievales aparezcan representados los símbolos del tetramorfos, bien dentro de estos triángulos o acompañando a la figura central. Así podemos verlos en los relieves de San Juan de Moarves de Ojeda (Palencia), el frontal de Equius o la iglesia de Santiago en Carrión de los Condes, aunque los ejemplos son innumerables. 
Todos estos ejemplos toman como fuente más antigua de inspiración uno de los primeros iconos conservados con esta temática que es el pantocrátor conservado en el convento de Santa Catalina del Sinaí (s. VI). Con el paso del tiempo ha comenzado a representar el libro abierto con distintas citas bíblicas en él, como podemos ver en esta capilla o la cripta de San Pietro de Pietrelcina (San Giovanni Rotondo, 2009), en la cual se escribe "Yo soy la vida». Junto a estas, podemos ver en la producción de Rupnik como poco a poco el pantocrátor ha adquirido más monumentalidad y así podemos verlo en los programas de la parroquia de Ravoledo (Italia, 2007), la iglesia de Santa Elena en Pertoca (Eslovenia, 2009), la capilla del Colegio Pontificio Irlandés (Roma, 2010), la iglesia del Colegio San Lorenzo (Roma, 2012) y la iglesia de San Juan Bautista de Smederevo (Serbia, 2013). Entre todos los ejemplos en los que Rupnik representa esta iconografía destacamos especialmente el caso de la iglesia de todos los santos en Lubliana (Eslovenia, 2009) ya que en ella ocupa la parte central del ábside formando parte una deesis muy similar a las obras de Argüello en Piacenza o Santa Catalina Labouré y también se representa en la decoración del sagrario.

Como hemos podido ver, la representación del pantocrátor que hacen ambos artistas sigue los cánones habituales y no presenta innovaciones iconográficas. Es un tipo iconográfico muy habitual que puede observarse en muchos momentos de la historia del arte, siendo especialmente en la época medieval uno de los más utilizados. Así podemos citar ejemplos como el dintel de sant Genis des Fontanes (Francia, 1020), las pinturas del panteón real de San Isidoro de León (s. XII), las pinturas del ábside de San Clemente de Tahull (c. 1223) o la portada de san Lázaro de Autum (c. 1130). Como inspiración clásica para el mundo del icono ruso, podemos referir el icono de El Salvador entre las potencias de Andrei Rublev (1410), el Salvador en el trono de la escuela de Novgorod (s. XVI) Siguiendo ejemplos como estos, Argüello y Rupnik retoman esta iconografía como clave simbólica y compositiva de sus creaciones lo cual resalta el sentido cristológico y escatológico de las mismas.

\section{CONCLUSIÓN}

La obra realizada por Kiko Argüello y Marko Ivan Rupnik en la catedral de Nuestra Señora la Real de la Almudena de Madrid entre 2004 y 2011 supone un ejemplo claro de la influencia que el icono oriental tiene en el arte religioso contemporáneo. El redescubrimiento de los iconos y la teología a ellos asociada ha trascendido en los últimos decenios los límites estrictos de la Iglesia de Oriente desarrollando un camino de influencias recíprocas de gran fecundidad. Supone además una clara superación de la crisis que la imagen sagrada había vivido en la primera mitad del siglo XX y enraíza con una producción de arte religioso contemporáneo especial- 
mente preocupada por la misión de la imagen en el espacio litúrgico. Esto se hace especialmente evidente al observar el planteamiento de la obra artística en Rupnik y Argüello. Más allá de las diferencias técnicas e iconográficas, ambos autores plantean una creación íntimamente ligada a su misión eclesial, proponiendo no solo una renovación estética del arte sacro, sino un marcado espíritu ecuménico y un objetivo catequético que asume y reinterpreta modelos propios de la tradición iconográfica oriental.

Sin embargo, esta concordancia de planteamientos no anula la creatividad artística de los autores obligando a una uniformidad estética, gracias a lo cual encontramos claras diferencias en el tratamiento de composiciones e iconografías. Así, podemos concluir que en la producción realizada en la seo madrileña Argüello se mantiene mucho más fiel a sus fuentes iconográficas, repitiendo las líneas generales de la composición y circunscribiendo cada escena al panel que la acoge, mientras que Rupnik busca intencionadamente la interrelación de las iconografías a través de líneas que unen a los personajes o mediante lecturas relacionales derivadas del diseño de conjunto.

Por todo ello, las aportaciones realizadas por Kiko Argüello y Marko Ivan Rupnik en la catedral de Madrid suponen un ejemplo de gran interés en el campo de la creación religiosa contemporánea, constatando las posibilidades de asunción y reinterpretación de modelos orientales como vehículo de renovación del arte sacro occidental.

\section{REFERENCIAS BIBLIOGRÁFICAS}

Argüello Wirz, F. (2000). Catequesis sobre el ciclo pictórico, Iglesia de la Santísima Trinidad. Piacenza.

Argüello, Wirz, F. (2001). Nueva estética y evangelización. En VV. AA., Catedral de la Almudena. Corona mistérica y vidrieras del ábside (p. 9). Madrid.

Argüello Wirz, F. (2012). El Kerigma. En las chabolas con los pobres. Madrid: Ed. Buenas Letras.

Baltasar, H. (1985-1989). Gloria. Una estética teológica. Madrid: Ed. Encuentro.

Casas Otero, J. (2003). Estética y culto iconográfico. Madrid: BAC.

Diéguez Melo, M. (2009). Estética arquitectónica del Camino Neocatecumenal. Estudio de sus fuentes y su influencia en la nueva arquitectura latinoamericana. En I. San Martín Cordova y P. Krieger (Coords.), Sacralización, culto y religiosidad 
en la arquitectura latinoamericana 1960-2010 (pp. 137-156). México: Ediciones Universidad Nacional Autónoma de México.

Diéguez Melo, M. (2018). La creación artística del Gremio 62: entre la individualidad estilística y el asociacionismo de inspiración medieval. En F. Villaseñor Sebastián, B. Alonso Ruiz, J. Gómez Martínez, J. J. Polo Sánchez y L. Sazatornil Ruiz (Eds.), La formación artística: creadores, historiadores, espectadores (pp. 680-692). Santander: Editorial Universidad de Cantabria.

Evdokimov, P. (1991). El arte del icono. Teología de la belleza. Madrid: Publicaciones Claterianas.

Govekar, N. y Rupnik, M. I. (2013). El rojo de la plaza de oro. Burgos: Monte Carmelo.

Ivanov, V. (1991). El gran libro de los iconos rusos. Madrid: Ediciones Paulinas, Madrid.

Marín Navarro, V. (2012). La renovación de la arquitectura cristiana contemporánea. El funcionalismo litúrgico alemán. Espacio, tiempo y forma, 25, pp. 201-222. https://doi.org/10.5944/etfvii.25.2012.9290.

Neocatechumenale Iter Statuta. (2002). Bilbao: Editorial Desclée de Brouwer.

Pasarelli, G. (1999). Iconos. Festividades bizantinas. Madrid: Ed. Libsa.

Plazaola Artola, J. (1965). Arte sacro actual. Madrid: BAC.

Rodríguez Velasco, M. (coord.). (2014). Tradición y modernidad en la obra de Marko Iván Rupnik.: Implicaciones teológicas, estéticas e iconográficas de los mosaicos del Centro Aletti. Madrid: CEU Ediciones.

Rodríguez Velasco, M. (2009). Iconografía, imagen y estética en los mosaicos de Marko Ivan Rupnik: una mirada desde la tradición. Debate Actual, 13, pp. 8-37.

Rodríguez Velasco, M. (2017). Reinterpretación de la concepción artística y los tipos iconográficos paleocristianos, bizantinos y románicos en los mosaicos del Centro Aletti (Roma): el programa iconográfico de la capilla del Colegio Mayor San Pablo (Madrid, octubre de 2009). Hispania Sacra, 69(140), pp. 755-764. https://doi.org/10.3989/hs.2017.047. 
Rupnik, M. I. (2000). Decir el hombre. Icono del Creador, revelación del amor. Madrid: PPC.

Rupnik, M. I. (2003). Los colores de la luz. Burgos: Monte Carmelo.

Rupnik, M. I. (2005). La via della belleza nell'arte contemporanea. Path, 4 (481-495).

Rupnik, M. I. (2009a). Implicaciones teológicas del mosaico: tradición y modernidad. En J. Prades (ed.), Dios es amor (pp. 61-71). Madrid: San Dámaso.

Rupnik, M. I. (2009b). Mosaici della Madre di Dio. Roma: Lipa.

Rupnik, M. I. Y Campatelli, M. (2009). Mosaici della Madre di Dio. Roma: Ed. Lipa.

Rupnik, M. I. y Cervera Barranco, P. (2008). La Catedral de la Almudena. Mosaicos de la Sacristía Mayor y la Sala Capitular. Burgos: Monte Carmelo.

Saenz, A. (1991). El icono: esplendor de lo sagrado. Argentina: Ediciones Glaudis.

Santos, A. (1984). Los evangelios apócrifos. Madrid: BAC

Špidlík, T. (2004). Miscellanea I. Alle fonti dell'Europa. Roma: Lipa.

Špidlík, T. y Rupnik, M. I. (2003). La fe según los iconos. Burgos: Monte Carmelo.

Spidlík, T. y Rupnik, M. I. (2013a). El conocimiento integral. La vía del símbolo. Madrid: BAC.

Špidlík, T. y Rupnik, M. I. (2013b). Teología de la evangelización desde la belleza. Madrid: BAC.

Uspenski, L. A. (2013). Teología del icono. Salamanca: Ediciones Sígueme.

VV. AA. (2000). San Bartolomé in Tuto. Una parroquia para el III Milenio. Iglesia y corona mistérica. Florencia.

VV. AA. (2000). SS. Trinitá Piacenza. I/ ciclo pittorico. Piacenza.

VV. AA. (2002). La Capilla "Redemptoris Mater» del Papa Juan Pablo II. Burgos: Monte Carmelo. 
VV. AA. (2004). Catedral de la Almudena. Corona Mistérica y Vidrieras del Ábside. Madrid.

VV. AA. (2012). Iconografía y Arte Cristiano. Madrid: San Pablo.

* Las imágenes de las obras de Marko Ivan Rupnik están tomadas de la página web del Centro Aletti https://www.centroaletti.com/[Visitado: 01/07/2020]. 